\title{
Primary to secondary organic aerosol: evolution of organic emissions from mobile combustion sources
}

\author{
A. A. Presto, T. D. Gordon, and A. L. Robinson \\ Center for Atmospheric Particle Studies, Carnegie Mellon University, Pittsburgh, PA, USA \\ Correspondence to: A. A. Presto (apresto@andrew.cmu.edu) \\ Received: 19 August 2013 - Published in Atmos. Chem. Phys. Discuss.: 16 September 2013 \\ Revised: 8 April 2014 - Accepted: 28 April 2014 - Published: 22 May 2014
}

\begin{abstract}
A series of smog chamber experiments were conducted to investigate the transformation of primary organic aerosol (POA) and formation of secondary organic aerosol (SOA) during the photooxidation of dilute exhaust from a fleet of gasoline and diesel motor vehicles and two gasturbine engines. In experiments where POA was present in the chamber at the onset of photooxidation, positive matrix factorization (PMF) was used to determine separate POA and SOA factors from aerosol mass spectrometer data. A 2-factor solution, with one POA factor and one SOA factor, was sufficient to describe the organic aerosol for gasoline vehicles, diesel vehicles, and one of the gas-turbine engines. Experiments with the second gas-turbine engine required a 3-factor PMF solution with a POA factor and two SOA factors. Results from the PMF analysis were compared to the residual method for determining SOA and POA mass concentrations. The residual method apportioned a larger fraction of the organic aerosol mass as POA because it assumes that all mass at $m / z 57$ is associated with POA. The POA mass spectrum for the gasoline and diesel vehicles exhibited high abundances of the $\mathrm{C}_{n} \mathrm{H}_{2 n+1}$ series of ions $(m / z 43,57$, etc.) and was similar to the mass spectra of the hydrocarbon-like organic aerosol factor determined from ambient data sets with one exception, a diesel vehicle equipped with a diesel oxidation catalyst. POA mass spectra for the gas-turbine engines are enriched in the $\mathrm{C}_{n} \mathrm{H}_{2 n-1}$ series of ions $(m / z 41,55$, etc.), consistent with the composition of the lubricating oil used in these engines. The SOA formed from the three sources exhibits high abundances of $m / z 44$ and 43, indicative of mild oxidation. The SOA mass spectra are consistent with less-oxidized ambient SV-OOA (semivolatile oxygenated organic aerosols) and fall within the triangular region of $f_{44}$ versus $f_{43}$ defined by ambient measurements. However there
\end{abstract}

is poor absolute agreement between the experimentally derived SOA mass spectra and ambient OOA factors, though this poor agreement should be expected based on the variability of ambient OOA factors. Van Krevelen analysis of the POA and SOA factors for gasoline and diesel experiments reveal slopes of -0.50 and -0.40 , respectively. This suggests that the oxidation chemistry in these experiments is a combination of carboxylic acid and alcohol/peroxide formation, consistent with ambient oxidation chemistry.

\section{Introduction}

Organic aerosols (OA) comprise roughly $50 \%$ of ambient fine particulate matter (PM) mass (Kanakidou et al., 2005). Understanding the sources and processing of $\mathrm{OA}$ is therefore critical to understanding the impacts of PM on climate and human health. Atmospheric OA is commonly classified as either primary organic aerosol (POA), which is directly emitted from combustion and other sources, or secondary organic aerosol (SOA), which results from oxidative atmospheric chemistry (Donahue et al., 2009). SOA dominates the OA burden, ranging from approximately two-thirds of OA mass in urban areas to greater than $90 \%$ of OA mass in downwind and rural areas (Zhang et al., 2007).

Much of what is known about the relative contributions of POA and SOA to ambient OA concentrations is the result of factor analysis of data collected with aerosol mass spectrometers (AMS). Zhang et al. $(2005,2007)$ used a custom principle component analysis to derive two factors from ambient AMS data. One factor, called hydrocarbon-like OA (HOA), is typically used as a proxy for POA and is defined by a large abundance of $m / z 57$, specifically $\mathrm{C}_{4} \mathrm{H}_{9}^{+}$, in the mass 
spectrum. The mass spectrum of the HOA factor has a high correlation with the OA mass spectrum obtained from fresh diesel engine exhaust (Canagaratna et al., 2004). The second factor, called oxygenated OA (OOA), is associated with ambient SOA and is defined by the large abundance of $m / z, 4$ $\left(\mathrm{CO}_{2}^{+}\right)$in the mass spectrum. $m / z$ 44 is the primary marker for organic aerosol oxidation (Canagaratna et al., 2007; $\mathrm{Ng}$ et al., 2011a; Zhang et al., 2005, 2007); it is associated with organic acids, and is indicative of highly aged and oxidized aerosol.

More recent work has focused on the use of positive matrix factorization (PMF) to determine OA factor profiles from ambient AMS data sets (Sun et al., 2012; Massoli et al., 2012; Ulbrich et al., 2009; $\mathrm{Ng}$ et al., 2010; Huffman et al., 2009; Lanz et al., 2007; Aiken et al., 2009; Docherty et al., 2008; Zhang et al., 2011; Sun et al., 2010). The OA factors derived from PMF analysis can be grouped into three main categories: (1) HOA, (2) one or more OOA factors, and (3) "specialty" factors associated with biomass burning (Huffman et al., 2009), cooking (Sun et al., 2012), or other sources. The mass spectrum of the HOA factor is generally consistent across many studies and geographic locations, and shares the characteristics, such as a high abundance of the series of $\mathrm{C}_{n} \mathrm{H}_{2 n+1}^{+}$ions, of the HOA factor determined by Zhang et al. (2005; Ng et al., 2011b). Most studies define two OOA factors: semivolatile OOA (SV-OOA), which is thought to correspond with fresh SOA, and low-volatility OOA (LVOOA), which is thought to correspond with more aged SOA. The mass spectrum of SV-OOA is characterized by $m / z 43$ (primarily $\mathrm{C}_{2} \mathrm{H}_{3} \mathrm{O}^{+}$) being the most abundant peak; $\mathrm{m} / \mathrm{z} 44$ $\left(\mathrm{CO}_{2}^{+}\right)$is also high in SV-OOA. This is indicative of the early stages of photochemical oxidation (Kroll et al., 2009). The mass spectrum of LV-OOA is dominated by the $\mathrm{CO}_{2}^{+}$ ion, suggesting that LV-OOA is at or near the oxidative endpoint for organic aerosol. While SV-OOA and LV-OOA factors share the same basic characteristics across a wide variety of studies, the specific mass spectra are more variable from study to study (and city to city) than the HOA mass spectra (Ng et al., 2010; Zhang et al., 2011; Ng et al., 2011b). This variability is evident in the scatter of ambient SV-OOA and LV-OOA factors when plotted in the "triangle plot" of $f_{44}$ versus $f_{43}$ ( $\mathrm{Ng}$ et al., 2010).

Two important questions regarding the ambient OA factors determined from PMF analysis are as follows: (1) are the factors physically interpretable, and (2) can the same factors be reproduced in the laboratory? The answer to the first question is typically "yes". Physical interpretability of the PMFderived OA factors is a litmus test for determining whether a factor profile is indeed a true factor or is spurious (i.e., the result of operator splitting) (Ulbrich et al., 2009). This manuscript attempts to address the second question.

Numerous smog chamber experiments have investigated the photochemical formation of SOA from dilute combustion exhaust from many sources, including diesel engines and vehicles (Chirico et al., 2010; Robinson et al., 2007; Sage et al.,
2008; Samy and Zielinska, 2010), automobiles (Nordin et al., 2012; Platt et al., 2012), gas-turbine engines (Miracolo et al., 2011, 2012), and biomass burning (Grieshop et al., 2009a, b; Hennigan et al., 2011; Heringa et al., 2011). In these experiments POA-containing emissions are injected into a smog chamber, and subsequently photooxidized to generate SOA. Thus, SOA and POA are present simultaneously, and a key aspect of these experiments is to separate POA and SOA abundance and composition (mass spectra).

Sage et al. (2008) developed the residual spectrum method to separate the mass spectra of POA and SOA. Much like the custom principle component analysis of Zhang et al. (2005), the residual spectrum analysis assumed that all of the signal at $m / z 57$ (for a unit mass resolution AMS) was associated with POA, and all of the $m / z 44$ signal was associated with SOA. Using this method, Sage et al. demonstrated that SOA formed from the photooxidation of dilute diesel engine exhaust had a similar mass spectrum to ambient oxidized organic aerosol.

One potential flaw of the residual spectrum method is that $m / z, 44$ and 57 are not strictly associated with SOA and POA, respectively. SOA can contain signal at $m / z, 57$ as either a reduced $\left(\mathrm{C}_{4} \mathrm{H}_{9}^{+}\right)$or partially oxidized $\left(\mathrm{C}_{3} \mathrm{H}_{5} \mathrm{O}^{+}\right)$ion, and POA can contain signal at $m / z$ 44. Chirico et al. (2010) and Miracolo et al. (2010) refined the residual spectrum method using high-resolution AMS data and only the reduced ion at $m / z 57$ $\left(\mathrm{C}_{4} \mathrm{H}_{9}^{+}\right)$as the POA tracer. However, as noted by Chirico et al., many ions could serve as the POA tracer for the residual method, and the ideal choice of tracer varies for different POA sources. Use of the wrong tracer, such as the use of the entire $m / z 57$ signal, can significantly over- or underestimate the POA concentration in the chamber, and this has a direct impact on the SOA mass spectrum calculated in the residual spectrum. Despite these flaws, the residual spectrum method remains a common tool for analyzing experiments probing SOA formation from dilute combustion exhaust.

The work presented in this manuscript seeks to use PMF to improve the estimates of POA and SOA in dilute exhaust smog chamber experiments. PMF has been used sparingly in the analysis of smog chamber data. Craven et al. (2012) used PMF to analyze SOA formed from the photooxidation of dodecane, but we are not aware of any applications of PMF to smog chamber experiments using dilute combustion exhaust as the SOA precursor.

In many ambient data sets the molecular oxygen-to-carbon $(\mathrm{O}: \mathrm{C})$ and hydrogen-to-carbon $(\mathrm{H}: \mathrm{C})$ ratios for the PMFderived OA factors (e.g., HOA, SV-OOA) are calculated from the AMS mass spectra either through direct elemental analysis of high-resolution mass spectral data or by using published relationships between $m / z 44$ and $\mathrm{O}: \mathrm{C}$, and $m / z \quad 43$ and $\mathrm{H}: \mathrm{C}$. H:C and O:C ratios can then be plotted in a van Krevelen plot to investigate the overall OA chemistry, as slopes in a van Krevelen plot are indicative of different oxidation mechanisms. For example, Heald et al. (2010) observed a van Krevelen slope of -1 for ambient OA data, 
suggesting that OA chemistry occurs via carboxylic acid formation and/or the addition of an alcohol and a carbonyl on different carbons. $\mathrm{Ng}$ et al. (2011a) observed a slope of -0.5 for ambient OOA factors. This suggests that OOA chemistry (e.g., conversion of SV-OOA to LV-OOA) occurs via a combination of acid/alcohol + carbonyl addition and alcohol or peroxide addition. In this manuscript, we use the van Krevelen plot to investigate the chemical transformations governing OA chemistry in these experiments and compare the chemical changes observed in the experiments to ambient data.

This paper investigates the composition and evolution of OA as measured by an AMS for a fleet of gasoline and diesel vehicles and for two gas-turbine engines. To our knowledge this is the first application of PMF to chamber experiments using dilute combustion exhaust, and therefore the data presented here are a validation of the PMF approach for this type of chamber experiment. Separate POA and SOA factors are derived for many experiments, and these factors are compared to ambient OA factors derived from PMF. We also compare the performance of the residual method and PMF at determining the POA-SOA split in these experiments.

\section{Materials and methods}

The experiments presented here investigate SOA production from gas-turbine engines, light-duty gasoline vehicles, and medium-duty diesel vehicles using a portable smog chamber. The full list of experiments considered here is listed in Table 1. Below we describe the operation and sampling from each source, followed by the procedures used for the smog chamber photooxidation experiments.

The smog chamber was a $7 \mathrm{~m}^{3}$ Teflon chamber (Hennigan et al., 2011; Miracolo et al., 2011, 2012; Presto et al., 2011). Before each experiment the chamber was cleaned by flushing with (high-efficiency particulate air) HEPA- and activatedcarbon-filtered air overnight. The chamber was cleaned to less than 10 particles $\mathrm{cm}^{-3}$ and $<5 \mathrm{ppb} \mathrm{NO}_{\mathrm{x}}$.

\subsection{Gasoline and diesel vehicles}

All experiments using light- and medium-duty vehicles were conducted at the California Air Resources Board's (CARB) Haagen-Smit Laboratory (HSL). The vehicle fleet considered here consisted of three LEV1 automobiles, four LEV2 automobiles, and two diesel vehicles. The California LEV1 standards cover vehicles for model years 1994-2003, and LEV2 covers model years 2004-2012. The model years of the specific vehicles tested for this study range from 1996 to 2010. The vehicles and model years are listed in Table 1. The make and model of each vehicle has been redacted and replaced with a code indicating the control level or fuel (LEV1, LEV2, or D), a numerical indicator for the vehicle, and a test number for the vehicle. For example, test LEV1-1.5 was the fifth test with vehicle LEV1-1. The vehicle fleet considered here is a subset of a larger fleet; full details of the entire vehicle fleet and the full suite of testing procedures are available elsewhere (Gordon et al., 2014a, b; May et al., 2013a, b, 2014).

Vehicles were tested on a chassis dynamometer using a cold-start Unified Cycle (UC). Figure S1 in the Supplement shows the speed trace for the UC. The UC has a three-phase structure, with $1435 \mathrm{~s}(28.9 \mathrm{~min})$ of driving time and a total distance of $17.6 \mathrm{~km}(11 \mathrm{mi})$. The first two phases of the UC are run consecutively, followed by a $10 \mathrm{~min}$, engine-off hot soak, and then a repeat of phase 1.

Emissions were sampled from the vehicle tailpipe using a constant volume sampler (CVS). A slipstream of the diluted emissions from the CVS was transferred into the portable smog chamber at a constant flow rate $(16 \mathrm{lpm})$ using two Dekati ejector dilutors. The dilution ratio in the ejector dilutors was $8-10: 1$. The transfer line was $12 \mathrm{~m}$ long, constructed out of electrically heated $\left(47^{\circ} \mathrm{C}\right), 1.27 \mathrm{~cm}(0.5 \mathrm{in}$.) outer-diameter (O.D.) Silcosteel tubing. The Dekati ejector diluters were also heated to $47^{\circ} \mathrm{C}$ and operated on HEPAand activated-carbon-filtered air. Heated lines were held at $47^{\circ} \mathrm{C}$ to maintain consistency with CFR-1065 procedures for filter sample collection from vehicles operating on dynamometers.

The smog chamber was located indoors, in a large airconditioned space; its temperature and humidity varied within $25-32^{\circ} \mathrm{C}$ and $30-50 \%$. Dilute emissions from the CVS were continuously added to the chamber over the entire UC but not during the 10 min hot-soak period. After filling, the exhaust inside the chamber was a factor of 200-300 more dilute than the conditions at the tailpipe, and PM concentrations were typically within the range of urban ambient conditions $\left(<10 \mu \mathrm{g} \mathrm{m}^{-3}\right)$ for all of the gasoline vehicles. In some diesel tests, primary PM concentrations were as high as $80 \mu \mathrm{g} \mathrm{m}^{-3}$, though $80-90 \%$ of this mass was black carbon (BC).

VOC concentrations were measured both in the CVS and the smog chamber. Total VOC emissions were measured in the CVS using an AVL AMA-4000 with flame ionization detection (FID). The total VOC concentration in the chamber was estimated using the CVS measurements and accounting for dilution, with $\mathrm{CO}_{2}$ used as the dilution tracer. The mixing ratios of approximately 20 individual VOCs inside the chamber were measured with a proton-transfer reaction mass spectrometer (PTR-MS, Ionicon Analytik). Mixing ratios of most individual VOCs measured in the smog chamber were typically less than $1 \mathrm{ppb}$, but were as high as $20 \mathrm{ppb}$ for the highest-emitting vehicle. The $\mathrm{NO}_{\mathrm{x}}$ concentrations inside the chamber after filling were between 0.1 and $2.4 \mathrm{ppm}$.

After adding exhaust, nitrous acid (HONO) was introduced into the chamber as an $\mathrm{OH}$ radical source. VOC: $\mathrm{NO}_{\mathrm{x}}$ ratios were adjusted, typically to approximately $3: 1 \mathrm{ppbC}$ ppb- $\mathrm{NO}_{\mathrm{x}}^{-1}$, typical of many urban environments, by the addition of propene. Propene was selected for VOC addition because it does not produce SOA upon 
Table 1. List of smog chamber experiments. Vehicles are identified by their model year and a unique identifier that indicates either the control level (LEV1 or LEV2) for gasoline vehicles or fuel (D) for diesel vehicles, a number assigned to the vehicle as part of the larger fleet presented in May et al. (2014), and the experiment number with that particular vehicle. Gas-turbine engine experiments are grouped based on the engine (CFM56 or T63).

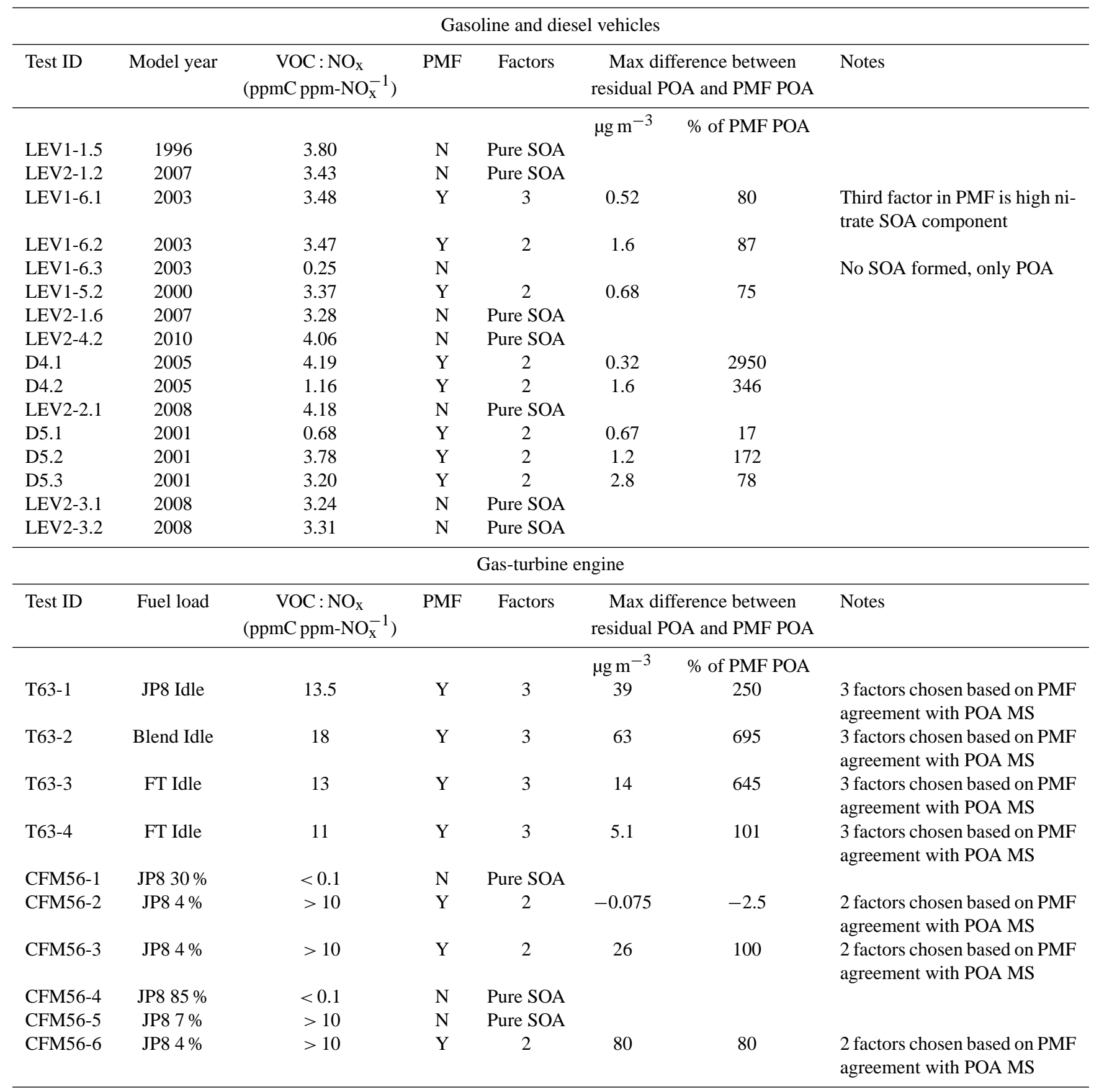

photooxidation, and has been used for $\mathrm{VOC}: \mathrm{NO}_{\mathrm{x}}$ conditioning in previous, similar experiments (Chirico et al., 2010). After $\sim 45 \mathrm{~min}$ of characterization of the primary emissions in the dark, the emissions were photooxidized by exposing them to UV lights (Model F40BL UVA, General Electric) continuously for $3 \mathrm{~h}$.

\subsection{Gas-turbine engines}

Two gas-turbine engines are considered here: a CFM56-2B1 gas-turbine engine mounted on a KC-135 Stratotanker airframe (Miracolo et al., 2011; Presto et al., 2011), and a T63 gas-turbine engine mounted in a test cell (Drozd et al., 2012; 
Miracolo et al., 2012). The gas-turbine engines were tested under conditions of constant load. The CFM56 test points were set based on fan speed (N1) to correspond to different engine thrust settings, including those prescribed by the International Civil Aviation Organization (ICAO) landingtakeoff (LTO) cycle. Tests were conducted at $4 \%$ rated thrust ("ground idle"), $7 \%$ thrust (idle as defined by ICAO), $30 \%$ thrust ("approach"), and $85 \%$ load (takeoff). The aircraft was operated on standard JP8 fuel.

Experiments with the T63 engine considered here were performed at idle load. The idle engine condition was set with no load on the dynamometer and fixed fuel flow of $8.5 \mathrm{~cm}^{3} \mathrm{~s}^{-1}$. The engine was operated on standard JP8 fuel, a synthetic fuel produced by the Fischer-Tropsch (FT) process using a coal feedstock, and a 50/50 volume blend of JP8 and FT.

Undiluted exhaust from each engine was sampled into a $0.27 \mathrm{~cm}(0.5$ in.) O.D. Silcosteel transfer line. The transfer line was held at $150^{\circ} \mathrm{C}$ to limit thermophoretic and condensational losses. The total length of the transfer line was $25 \mathrm{~m}$ for experiments with the CFM56 engine and $10 \mathrm{~m}$ for experiments with the T63 engine. Two Dekati ejector diluters, held at $150^{\circ} \mathrm{C}$ and using dilution air heated to the same temperature, were placed at the end of the transfer line.

For experiments with both engines the smog chamber was located outdoors and was not temperature-controlled. Dilute exhaust was added to the chamber for 5-30 min, corresponding to approximately $0.07-0.4 \mathrm{~m}^{3}$ of total volume (exhaust plus dilution air) added to the chamber. Initial total primary particle mass concentrations inside the chamber ranged from 1 to $77 \mu \mathrm{g} \mathrm{m}^{-3}$, representative of ambient- to plume-like conditions. The average dilution ratio between the chamber and the engine exit plane, estimated from background-corrected $\mathrm{CO}_{2}$ measurements, was approximately 120 across the set of experiments. Photooxidation was initiated by exposing the chamber to ambient sunlight. Unlike the gasoline and diesel vehicle experiments, HONO was not added to the chamber to boost $\mathrm{OH}$ radical concentrations.

The VOC : $\mathrm{NO}_{\mathrm{x}}$ ratio varied widely across the set of experiments. Engine-out VOCs were measured with an FID for the T63 experiments, and corrected for dilution to the chamber using $\mathrm{CO}_{2}$ as the dilution tracer. Therefore VOC: $\mathrm{NO}_{\mathrm{x}}$ ratios are available for experiments with the T63. Total VOCs were not measured for the CFM56 engine, and therefore VOC : $\mathrm{NO}_{\mathrm{x}}$ ratios are estimated using published VOC emissions for similar engines (Anderson et al., 2006; Spicer et al., 1992; Wey et al., 2006). In general, experiments conducted at idle load had VOC: $\mathrm{NO}_{\mathrm{x}}>10 \mathrm{ppbC}$ ppb-NO $\mathrm{NO}_{\mathrm{x}}^{-1}$, whereas experiments at higher loads had VOC: $\mathrm{NO}_{\mathrm{x}}<1 \mathrm{ppbC}$ ppb$\mathrm{NO}_{\mathrm{x}}^{-1}$.

In addition to differences in emissions from the combustion sources, there are three significant, largely systematic differences between the experiments with gas-turbine engines and the experiments with gasoline and diesel vehicles: (1) HONO was added as a radical precursor for all of the gasoline and diesel experiments, but not the gas-turbine engine experiments; (2) the VOC: $\mathrm{NO}_{\mathrm{x}}$ ratio was conditioned to approximately $3: 1 \mathrm{ppbCppb}-\mathrm{NO}_{\mathrm{x}}^{-1}$ for the gasoline and diesel vehicle experiments, but was not conditioned for the gas-turbine experiments; and (3) different light sources (ambient versus UV black lights) were used for the sets of experiments.

Each of these differences can impact SOA chemistry and the extent of SOA formation. Adding $\mathrm{OH}$ precursors such as $\mathrm{HONO}$ boosts $\mathrm{OH}$ production and drives faster reaction kinetics. The choice whether or not to use $\mathrm{HONO}$ as an $\mathrm{OH}$ radical precursor was largely ad hoc. Most experiments with gas-turbine engine exhaust produced significant SOA without the addition of HONO (Miracolo et al., 2011, 2012), and therefore it was deemed unnecessary for these experiments. HONO was added to all experiments with gasoline and diesel vehicles by design; we did not investigate SOA formation from these sources without HONO present in the smog chamber. In general, dilute exhaust concentrations in the chamber were lower in the gasoline and diesel experiments than in the gas-turbine experiments, and this was used in part to justify the use of HONO in the gasoline and diesel tests.

Similar $\mathrm{OH}$ concentrations were observed in the gasturbine and vehicle exhaust experiments. Average $\mathrm{OH}$ concentrations in the gas-turbine experiments were 5$12 \times 10^{6}$ molecule $\mathrm{cm}^{-3}$ (Miracolo et al., 2011, 2012). For gasoline and diesel experiments, the average $\mathrm{OH}$ concentration was approximately $5 \times 10^{6}$ molecule $\mathrm{cm}^{-3}$ (Gordon et al., 2014a, b). Thus, any differences between the two sets of experiments resulting from the addition of HONO should not be the result of different $\mathrm{OH}$ radical levels or integrated $\mathrm{OH}$ exposures.

The addition of $\mathrm{HONO}$ also adds $\mathrm{NO}_{\mathrm{x}}$ to the chamber and perturbs the VOC: $\mathrm{NO}_{\mathrm{x}}$ ratio, which in turn impacts the reaction pathway of peroxy radicals. At low VOC: $\mathrm{NO}_{\mathrm{x}}$ ratios ( $<\sim 3$ ppbC ppb-NO $-\mathrm{NO}_{\mathrm{x}}^{-1}$; high- $\mathrm{NO}_{\mathrm{x}}$ conditions), peroxy radicals primarily react with $\mathrm{NO}$ to form $\mathrm{NO}_{2}$ and an alkoxy radical. Peroxy radicals can also react with NO to form organic nitrates, and nitrate-containing SOA species are observed under high- $\mathrm{NO}_{\mathrm{x}}$ conditions (Ziemann and Atkinson, 2012). At high VOC: $\mathrm{NO}_{\mathrm{x}}\left(>10 \mathrm{ppbC}\right.$ ppb-NO $\mathrm{NO}_{\mathrm{x}}^{-1}$; low- $\mathrm{NO}_{\mathrm{x}}$ conditions) peroxy radicals react primarily with $\mathrm{HO}_{2}$ radicals to form organoperoxy species (Docherty et al., 2005; Ziemann and Atkinson, 2012). Due in large part to these differences in chemical reaction pathways, SOA mass yields for individual precursor VOCs are dependent on VOC : $\mathrm{NO}_{\mathrm{x}}$ ratios $(\mathrm{Ng}$ et al., 2007; Presto et al., 2005). Changes in VOC: $\mathrm{NO}_{\mathrm{x}}$ can therefore impact both the extent of SOA formation and the composition of the resultant SOA.

The source and intensity of UV radiation can impact SOA formation by changing $\mathrm{OH}$ radical concentrations and/or the extent of photolysis (Warren et al., 2008). Measurements of $\mathrm{NO}_{2}$ photolysis rates $\left(\mathrm{NO}_{2}\right)$ and UV intensity are not available for experiments conducted using natural sunlight. 
For experiments using UV black lights, $j_{\mathrm{NO}_{2}}$ was $0.03-$ $0.06 \mathrm{~min}^{-1}$.

\subsection{Instrumentation}

A suite of instruments was used to characterize gas- and particulate-phase pollutants inside the chamber. A sevenwavelength aethalometer (Magee Scientific) was used to measure BC concentrations. Concentrations of selected VOCs were measured with a proton transfer reaction mass spectrometer (PTR-MS, Ionicon Analytik) operating in selected ion mode. Gas-phase concentrations inside the smog chamber were quantified using $\mathrm{CO}_{2}$ (LI-820, Li-Cor Biosciences), $\mathrm{NO}_{\mathrm{x}}$, and $\mathrm{O}_{3}$ (Models 200A and 400E, APITeledyne) monitors.

Aerosol composition and size were monitored with a quadrupole AMS operating at unit mass resolution. (Canagaratna et al., 2007; Jayne et al., 2000) The fragmentation table of Allan et al. (2004) was used to interpret the AMS data. The contribution of gas-phase $\mathrm{CO}_{2}$ to the AMS $m / z 44$ signal was corrected by replacing the assumed $\mathrm{CO}_{2}$ concentration of $370 \mathrm{ppm}$ in the fragmentation table with the measured $\mathrm{CO}_{2}$ concentrations in the smog chamber as a function of time. This method of $\mathrm{CO}_{2}$ correction is similar to the method recently validated by Collier and Zhang (2013).

There was no evidence of organic particle signal at $m / z 28$ $\left(\mathrm{CO}^{+}\right)$either before or after the start of photooxidation. This was verified through analysis of the pTOF data and by examining the time series of the $m / z 28$ raw signal strength as described by Grieshop et al. (2009a).

The AMS fragmentation table apportions OA loadings at several mass-to-charge ratios relative to the OA signal at $m / z$ 44. The Allan et al. (2004) fragmentation table used here apportions no $\mathrm{OA}$ mass at $m / z 28\left(\mathrm{CO}^{+}\right)$and sets OA mass at $m / z 18\left(\mathrm{H}_{2} \mathrm{O}^{+}\right)$equal to $\mathrm{OA}$ mass at $m / z 44$ $\left(\mathrm{CO}_{2}^{+}\right)$. Aiken et al. (2008), using a high-resolution AMS, observed that for many ambient data sets, the default fragmentation table underestimated the $\mathrm{CO}^{+}$signal and overestimated $\mathrm{H}_{\mathrm{x}} \mathrm{O}^{+}\left(\mathrm{H}_{2} \mathrm{O}^{+}, \mathrm{HO}^{+}, \mathrm{O}^{+}\right)$signals. Therefore, Aiken suggested a revision to the fragmentation table that sets $\mathrm{OA}$ mass attributable to $\mathrm{CO}^{+}$equal to $\mathrm{CO}_{2}^{+}$, and reduced $\mathrm{H}_{2} \mathrm{O}^{+}$ to $22.5 \%$ of $\mathrm{CO}_{2}^{+}$. We use the Allan et al. fragmentation table because it is consistent with our observation of zero OA mass at $m / z 28$.

The particulate nitrate signal was apportioned between organic and inorganic nitrates using the approach of Farmer et al. (2010). When nitrates fragment in the AMS, organic nitrates produce a different ratio of $\mathrm{NO}^{+}$to $\mathrm{NO}_{2}^{+}$(" $\mathrm{NO}_{\mathrm{x}}^{+}$ ratio") than inorganic nitrates. By comparing the observed $\mathrm{NO}_{\mathrm{x}}^{+}$ratio to the $\mathrm{NO}_{\mathrm{x}}^{+}$ratios of reference organic and inorganic nitrates, we calculated the organic fraction of the total nitrate signal: $x=\left(R_{\mathrm{obs}}-R_{\mathrm{AN}}\right)\left(1+R_{\mathrm{ON}}\right) /\left[\left(R_{\mathrm{ON}}-R_{\mathrm{AN}}\right)\right.$ $\left(1+R_{\mathrm{obs}}\right)$ ], where $R_{\mathrm{obs}}$ is the observed $\mathrm{NO}_{\mathrm{x}}^{+}$ratio in an experiment, $R_{\mathrm{AN}}$ is the $\mathrm{NO}_{\mathrm{x}}^{+}$ratio for ammonium nitrate, and $R_{\mathrm{ON}}$ is the $\mathrm{NO}_{\mathrm{x}}^{+}$ratio for organic nitrate. A minor fraction (typically $<5 \%$ ) of the nitrate mass was attributable to organics.

Many studies have performed elemental analysis on highresolution AMS data to determine $\mathrm{O}: \mathrm{C}$ and $\mathrm{H}: \mathrm{C}$ atomic ratios. Aiken et al. $(2007,2008)$ first presented the elemental analysis method for high-resolution AMS data. They used single-component, laboratory-generated OA to calibrate the method and verified it with ambient and chamber data. While elemental analysis cannot be performed directly on unit mass resolution AMS data, Aiken et al. (2008) presented a parameterization for converting $f_{44}$ (the fraction of OA signal at $m / z$ 44) to O : C. Ng et al. (2011a) presented a similar parameterization for converting $f_{43}$ to $\mathrm{H}: \mathrm{C}$. These parameterizations are independent of the version of the fragmentation table used, as $m / z 43$ and 44 are not included in the fragmentation table amendments presented by Aiken et al. (2008). In this study, we use the $f_{44}-\mathrm{O}: \mathrm{C}$ and $f_{43}-\mathrm{H}$ : C relationships to map unit mass resolution AMS data into van Krevelen space.

\subsection{Determination of POA-SOA split}

The experiments in Table 1 can be grouped into two categories. In $40 \%$ of the experiments $(N=11)$, there was not an appreciable POA concentration $\left(<0.5 \mu \mathrm{g} \mathrm{m}^{-3}\right)$ in the smog chamber after filling with dilute exhaust. These experiments are considered "pure SOA" experiments. POA was present in the remaining experiments $(N=16)$.

When POA was present in the chamber after filling with dilute exhaust, two methods were used to determine the mass concentrations of POA and SOA after the onset of photooxidation. One method is the residual spectrum method of Sage et al. (2008). $m / z 57$ was used as the POA tracer for the residual method. As described above, this can lead to the incorrect apportionment of some SOA as POA if there is $m / z 57$ present in the SOA mass spectrum and/or $m / z 44$ present in the POA.

Positive matrix factorization (Paatero, 1997; Paatero and Tapper, 1994) was also used to deconvolve POA and SOA factors. The PMF analysis of AMS data followed the method and tools outlined by Ulbrich et al. (2009). PMF was run in exploration mode; solutions using between 1 and 4 factors and FPEAK values between -1 and 1 were investigated. In most cases, the solution at FPEAK $=0$ was selected. Diagnostic plots of PMF fits to several experiments are available in the Supplement.

\section{Results and discussion}

\subsection{Typical experiment and PMF analysis}

\subsubsection{Gas and diesel vehicles}

Figure 1 shows the time series for experiment LEV1-5.2. This was a typical experiment with POA present in the 

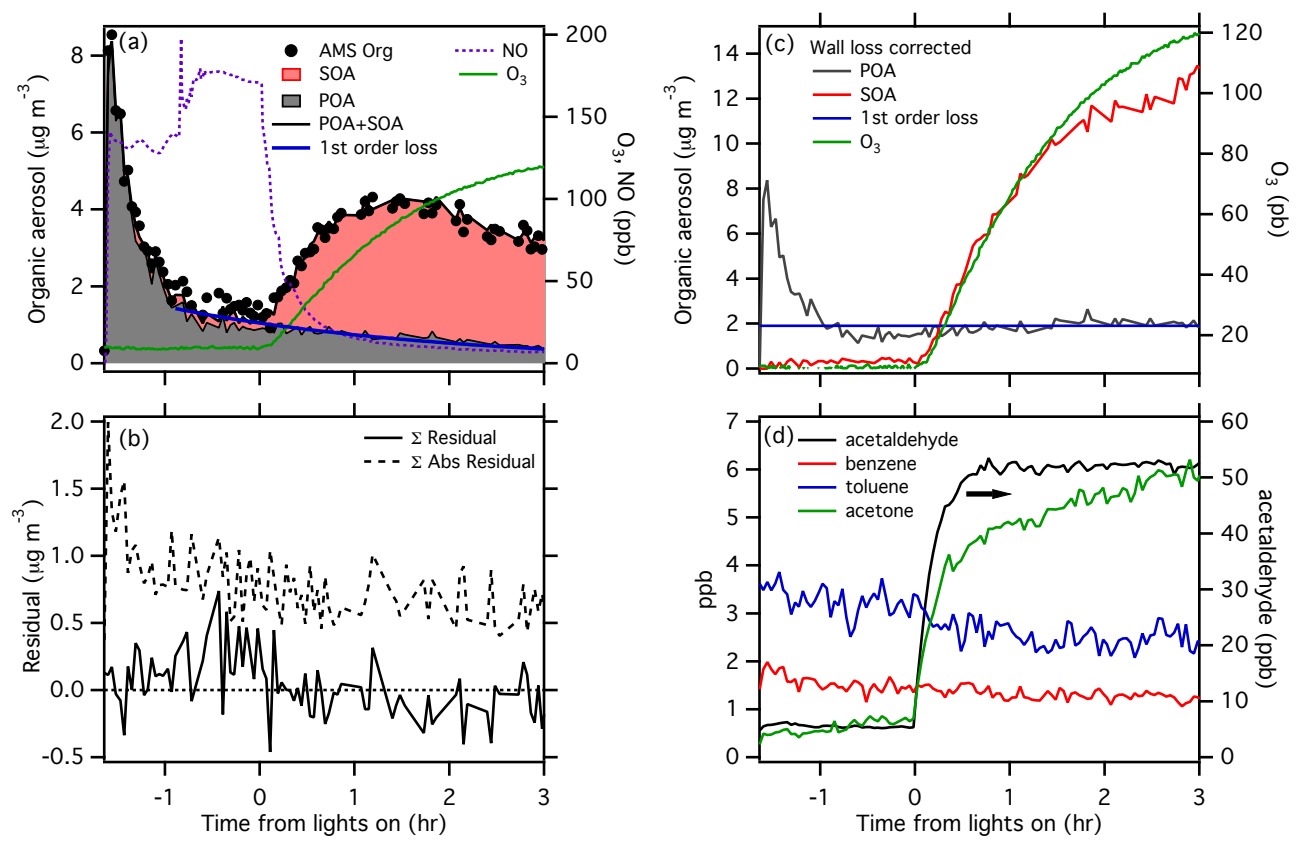

Figure 1. Time series of a typical experiment (LEV1-5.2). (a) Diluted exhaust was introduced to the chamber starting at $t=-1.4 \mathrm{~h}$ and coincides with increases in OA and NO concentrations in the chamber. Chamber filling ended at $t=-0.74 \mathrm{~h}$, at which point $\mathrm{HONO}$ and propene were added to the chamber; addition of HONO also introduces additional NO. The observed OA concentration increased after the start of oxidation, indicating production of SOA. Red and grey shading indicate the POA and SOA factors determined from PMF analysis. The blue line shows a predicted first-order wall loss rate for POA after the completion of the driving cycle based on black carbon wall loss. (b) Residual of the PMF solution. (c) Particle-phase concentrations from (a) after corrections for wall losses. (d) Concentrations of selected VOCs as measured with a PTR-MS.

chamber after filling with diluted exhaust. Figure 1a shows aerosol data without correction for losses to the chamber walls as well as gas-phase concentrations of $\mathrm{NO}$ and $\mathrm{O}_{3}$, and Fig. 1c shows the aerosol data after correction for wall losses. Figure S2 in the Supplement shows a similar time series for an experiment without POA in the chamber (pure SOA, LEV2-1.2).

The experiments consist of four phases: (I) introduction of diluted exhaust into the clean chamber over the course of the Unified Cycle, (II) characterization of the primary emissions in the chamber $(\sim 0.5-1 \mathrm{~h})$, (III) photooxidation $(\sim 3 \mathrm{~h})$, and (IV) characterization of aged aerosol in the dark $(\sim 1 \mathrm{~h})$. For experiment LEV1-5.2 shown in Fig. 1, chamber filling began at $t=-1.39 \mathrm{~h}$ and finished at $t=-0.74 \mathrm{~h}$. Introduction of dilute exhaust into the smog chamber is indicated by a rapid rise in OA and NO concentrations, which increase to approximately $8 \mu \mathrm{g} \mathrm{m}^{-3}$ and $125 \mathrm{ppb}$ in the first few minutes after the start of the vehicle driving cycle.

The chamber was continuously filled with dilute exhaust for the entire $28.9 \mathrm{~min}$ of the Unified Cycle. POA (and PM) emissions are dominated by the "cold start" - the first few minutes of vehicle operation. Therefore an initial burst of POA is observed followed by a rapid decline in observed OA concentrations due to a combination of wall losses and dilution. NO emissions, on the other hand, are more constant over the course of the driving cycle, and NO concentrations in the chamber do not undergo the same rapid drop as POA concentrations.

After the completion of the driving cycle the POA was characterized for approximately $45 \mathrm{~min}$ in the dark chamber while HONO and propene were added to the chamber. During this period the observed concentration of POA fell because of wall losses (Fig. 1a), but the wall-loss-corrected POA concentration (Fig. 1c) remained essentially constant at $1.9 \mu \mathrm{g} \mathrm{m}^{-3}$. Addition of HONO to the chamber produced a rapid increase in $\mathrm{NO}$ and $\mathrm{NO}_{2}$ (not shown) concentrations. There was no evidence of chemistry during the dark POA characterization period: OA mass did not increase, the mass spectrum of the observed POA remained constant, and concentrations of gases, with the exception of intentionally added propene and $\mathrm{NO}_{\mathrm{x}}$, remained constant.

Photooxidation was initiated at $t=0$. In this experiment SOA formation was prompt, and the measured OA concentration increased from $\sim 1$ to $\sim 4 \mu \mathrm{g} \mathrm{m}^{-3}$ in $1.5 \mathrm{~h}$. Wall-losscorrected OA concentrations (Fig. 1c) increased throughout the entire $3 \mathrm{~h}$ photooxidation period. The rise in OA concentration was mirrored by increases in $\mathrm{O}_{3}$. As shown in Fig. 1c, $\mathrm{O}_{3}$ and SOA increased at roughly the same pace throughout the photooxidation period of the experiment. 
SOA formation was accompanied by the consumption of known SOA precursors such as toluene and benzene and the formation of small, oxidized VOCs such as acetone and acetaldehyde (Fig. 1d). Acetaldehyde formation was more rapid than SOA formation. The acetaldehyde concentration reached $50 \mathrm{ppb}$ within approximately $30 \mathrm{~min}$ of the start of photooxidation, and remained constant after the initial rise. Acetone concentrations also rose rapidly for approximately the first $20 \mathrm{~min}$ after the start of photooxidation, and increased more slowly for the remainder of the experiment.

Figure 1a also shows the results of a 2-factor PMF solution with FPEAK $=0$. The 2-factor solution yields distinct POA and SOA factors. The temporal split between the two factors is "clean"; i.e., the concentration of the SOA factor is essentially zero $\left(<0.3 \mu \mathrm{g} \mathrm{m}^{-3}\right)$ for the entire chamber filling and primary characterization period $(t<0)$ of the experiment. This is expected based on the design of the experiment. By definition, the SOA concentration is strictly zero for $t<0$, and the PMF solution captures this fact. The observed, non-wall-loss-corrected concentration of the SOA factor increases dramatically with the onset of photooxidation, peaking at approximately $3.5 \mu \mathrm{g} \mathrm{m}^{-3}$.

After initially spiking when dilute exhaust was first added to the chamber $(t=-1.65)$, the concentration of the POA factor decreased because of wall losses and dilution during chamber filling. The suspended concentration of the POA factor continued to decrease during the photooxidation portion of the experiment because of wall losses.

In many smog chamber studies, SOA is calculated as the difference between the total OA mass concentration and the assumed concentration of conserved (i.e., nonevaporating) seed particles. The seed particles are assumed to undergo first-order loss to the chamber walls, and the wall loss rate constant $\left(k_{\mathrm{wall}}\right)$ can be constrained by tracers such as black carbon or particulate sulfate (Hildebrandt et al., 2009; Grieshop et al., 2009b; Hennigan et al., 2011). In experiments where POA is present, it is typically assumed to be a conserved tracer, and the SOA concentration is therefore the difference between the total OA and the calculated POA concentrations (Weitkamp et al., 2007).

The blue line in Fig. 1a shows the POA concentration for $t>-0.75 \mathrm{~h}$ (after filling was complete) assuming first-order wall loss. The wall loss rate was determined from black carbon decay. The traditional definition of POA (blue line) and the PMF-derived POA factor have a similar time trend, suggesting that for this experiment the traditional method of determining the split between POA and SOA is robust. Figure $1 \mathrm{c}$ shows the POA time series after correction for wall losses. In this experiment, the assumed first-order POA decay yields a horizontal line at $1.9 \mu \mathrm{g} \mathrm{m}^{-3}$, and the POA factor follows this horizontal line $\left(1.9 \pm 0.25 \mu \mathrm{g} \mathrm{m}^{-3}\right)$ for the entire $3 \mathrm{~h}$ of photooxidation.

Figure $1 \mathrm{~b}$ shows both the sum of the residuals and the absolute sum of the residuals for the 2-factor PMF solution. The value of the residual is less than $0.5 \mu \mathrm{g} \mathrm{m}^{-3}$

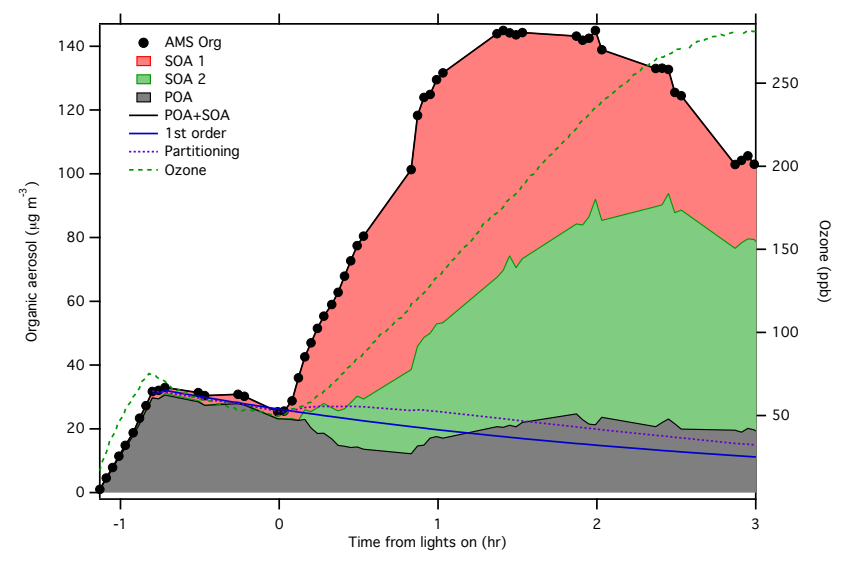

Figure 2. Time series of a typical gas-turbine engine experiment (T63-1). Non-wall-loss-corrected OA mass and $\mathrm{O}_{3}$ concentration are shown. Red, grey, and green shading indicate the results of a 3-factor PMF solution with one POA factor and two SOA factors. The blue line shows a predicted first-order wall loss rate for POA based on black carbon wall loss, and the dashed purple line shows the predicted POA partitioning based on the volatility distribution of the fresh emissions.

( $\Sigma$ residual $/ \Sigma \mathrm{OA}<0.2$ ). The 2 -factor solution is relatively insensitive to FPEAK. Varying FPEAK between -1 and 1 did not have a significant impact on the magnitude of the residual, the ratio $\Sigma$ residual / $\Sigma O A$, or the mass spectra or time series of the two factors (see Fig. S3 in the Supplement for PMF diagnostic plots of the 2-factor solution).

Adding a third or fourth factor does not improve the performance of the PMF solution. The residual for the 3factor solution is nearly identical to the 2-factor solution. Adding additional factors does not substantially improve

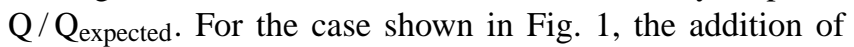
a third factor reduces $\mathrm{Q} / \mathrm{Q}_{\text {expected }}$ by $7 \%$. Additionally, the concentration of the third factor is nearly constant with time, and is associated with neither the addition of dilute exhaust to the chamber nor photooxidation, and therefore is not physically interpretable. Diagnostic plots for the 3-factor solution are presented in the Supplement in Fig. S4.

\subsubsection{Gas-turbine engines}

Figure 2 shows a time series and PMF solution for a typical experiment with a gas-turbine engine (T63-1). In this experiment JP8 fuel was used and the engine was operated at idle load. This experiment, along with all gas-turbine engine experiments at idle load, exhibited a very large increase in OA mass upon photooxidation. In several experiments (T63-1 and -2; CFM56-2 and -6) the suspended OA mass concentration increased to above $100 \mu \mathrm{g} \mathrm{m}^{-3}$. The suspended OA mass shown in Fig. 2 increased from approximately $25 \mu \mathrm{g} \mathrm{m}^{-3}$ at $t=0$ to $140 \mu \mathrm{g} \mathrm{m}^{-3}$ at $t=1.5 \mathrm{~h}$.

A 3-factor PMF solution, with one POA factor and two SOA factors, was required to describe the experiment shown 
in Fig. 2. Diagnostic plots are shown in Fig. S5 in the Supplement. All of the idle load experiments with the T63 engine required 3 -factor solutions. Ground idle (4\%) load experiments with the CFM56 engine, on the other hand, required only a 2-factor solution. The decision between 2- and 3factor solutions for these experiments was dependent upon several factors, including the PMF diagnostics $\left(\mathrm{Q} / \mathrm{Q}_{\mathrm{exp}}\right.$, residual) as well as the agreement between the observed POA mass spectrum and the mass spectrum of the PMF POA factor. Agreement between the measured and PMF-derived POA mass spectra is discussed in a later section.

The time series of the POA factor mass concentration for experiment T63-1 is shown in grey in Fig. 2. Figure 2 also shows a predicted first-order POA wall loss curve in blue. Unlike the case shown in Fig. 1, the first-order POA loss does a poor job of representing the time trace of the PMFderived POA factor for $t>0 \mathrm{~h}$. The POA factor concentration decreases faster than wall loss for the first 15 min after the start of photooxidation. This is due to the POA evaporating slightly as the surrounding vapors are rapidly consumed (Robinson et al., 2007). The POA factor concentration subsequently increases from 12.2 to $24.7 \mu \mathrm{g} \mathrm{m}^{-3}$ between $t=1 \mathrm{~h}$ and $t=2 \mathrm{~h}$. This increase is driven by partitioning of POA vapors to the particle phase with increasing organic aerosol concentration $\left(\mathrm{C}_{\mathrm{OA}}\right)$, and is not captured by the assumed first-order wall loss curve shown in blue.

The purple dashed line in Fig. 2 shows the predicted POA partitioning based on the volatility distribution and measured total organic emissions for this experiment (Presto et al., 2012). The predicted partitioning fails to capture the POA evaporation immediately after the start of photooxidation, but it does provide a reasonable estimate for the magnitude of the POA concentration for $t>2 \mathrm{~h}$ and confirms that increases in the concentration of the POA factor for $t=1-2 \mathrm{~h}$ are driven by partitioning.

Two SOA factors were determined from PMF for the experiment shown in Fig. 2. The factor labeled "SOA 1" appears immediately after the onset of photooxidation at $t=0$. The observed concentration of SOA 1 peaks at approximately $70 \mu \mathrm{g} \mathrm{m}^{-3}$ at $t=1.5 \mathrm{~h}$; it is responsible for $50 \%$ of the observed OA mass at this point in the experiment. SOA 1 is the primary driver for the increase in OA mass during the first $1.5 \mathrm{~h}$ of photooxidation.

A second SOA factor, "SOA 2", also appears immediately upon the start of photooxidation, but its concentration does not peak until later in the experiment, at $t=2.5 \mathrm{~h}$. At this time, the suspended SOA 2 concentration is approximately $70 \mu \mathrm{g} \mathrm{m}^{-3}$, and constitutes $55 \%$ of the observed OA mass. As with the SOA factor shown in Fig. 1 for gasoline vehicles, the time trend of SOA 2 roughly follows the trajectory of $\mathrm{O}_{3}$ formation.

\subsection{Temporal behavior of POA factors}

\subsubsection{POA partitioning}

Nearly all chemical transport models assume that OA forms a single pseudo-ideal solution and undergoes absorptive partitioning. Gas-particle partitioning is therefore governed by Raoult's law:

$\mathrm{C}_{\mathrm{OA}}=\sum_{i} \mathrm{C}_{i}\left(1+\frac{\mathrm{C}_{i}^{*}(T)}{\mathrm{C}_{\mathrm{OA}}}\right)^{-1}$.

$\mathrm{C}_{\mathrm{OA}}$ is the total concentration of organic aerosol, and serves as the absorbing medium. Each of the species $i$ can be an individual compound or a lumped surrogate in the volatility basis set (Donahue et al., 2006, 2011, 2012). C* is the effective saturation concentration $\left(\mu \mathrm{g} \mathrm{m}^{-3}\right)$, and the temperature dependence of $\mathrm{C}^{*}(T)$ is governed by the Clausius-Clapeyron equation.

During photooxidation, changes in POA partitioning can perturb the POA concentration in the chamber. In nearly all experiments considered here, the temperature in the smog chamber rose slightly $\left(5-10^{\circ} \mathrm{C}\right)$ during photooxidation; this causes net evaporation of POA species. In addition to temperature-induced evaporation, the vapors in equilibrium with the POA are consumed, e.g., by reaction with $\mathrm{OH}$ radicals, during photooxidation. Consumption of these vapors should drive additional POA evaporation. POA evaporation is countered by an increase in $\mathrm{C}_{\mathrm{OA}}$, which is driven by SOA formation and causes additional POA to condense.

The combined effects of temperature, chemical consumption of vapors, and increasing $\mathrm{C}_{\mathrm{OA}}$ on $\mathrm{POA}$ partitioning can be investigated with simple partitioning and kinetics calculations. For example POA partitioning can be calculated from Eq. (1) using the one-dimensional volatility basis set with logarithmically spaced bins of $C^{*}$ (Donahue et al., 2006), the measured temperature in the smog chamber, $\mathrm{C}_{\mathrm{OA}}$ determined from AMS measurements, the volatility distribution $\left(f_{i}\right)$ of the POA, and the first-order wall loss rate constant in the chamber.

The consumption of vapors in phase equilibrium with POA can be estimated using Eq. (2):

$\frac{d C_{i}^{\mathrm{VAP}}}{d t}=-k_{\mathrm{OH}}[\mathrm{OH}]\left[C_{i}^{\mathrm{VAP}}\right]$.

$\mathrm{OH}$ radical concentrations can be estimated from the decay of VOCs using the PTR-MS (Gordon et al., 2014a, b; Miracolo et al., 2011, 2012), and $k_{\mathrm{OH}}$ was assumed to be $3 \times 10^{-11}$ molecule ${ }^{-1} \mathrm{~cm}^{3} \mathrm{~s}^{-1}$ (Atkinson and Arey, 2003). Analysis of POA evolution using Eqs. (1) and (2) ignores the impact of the Kelvin effect and nonequilibrium mass transfer between the condensed and vapor phases (May et al., 2012), but should provide a reasonable estimate of the overall changes in POA partitioning for a given experiment.

The experiments considered here can be grouped into four classes based on the time evolution and partitioning of the 

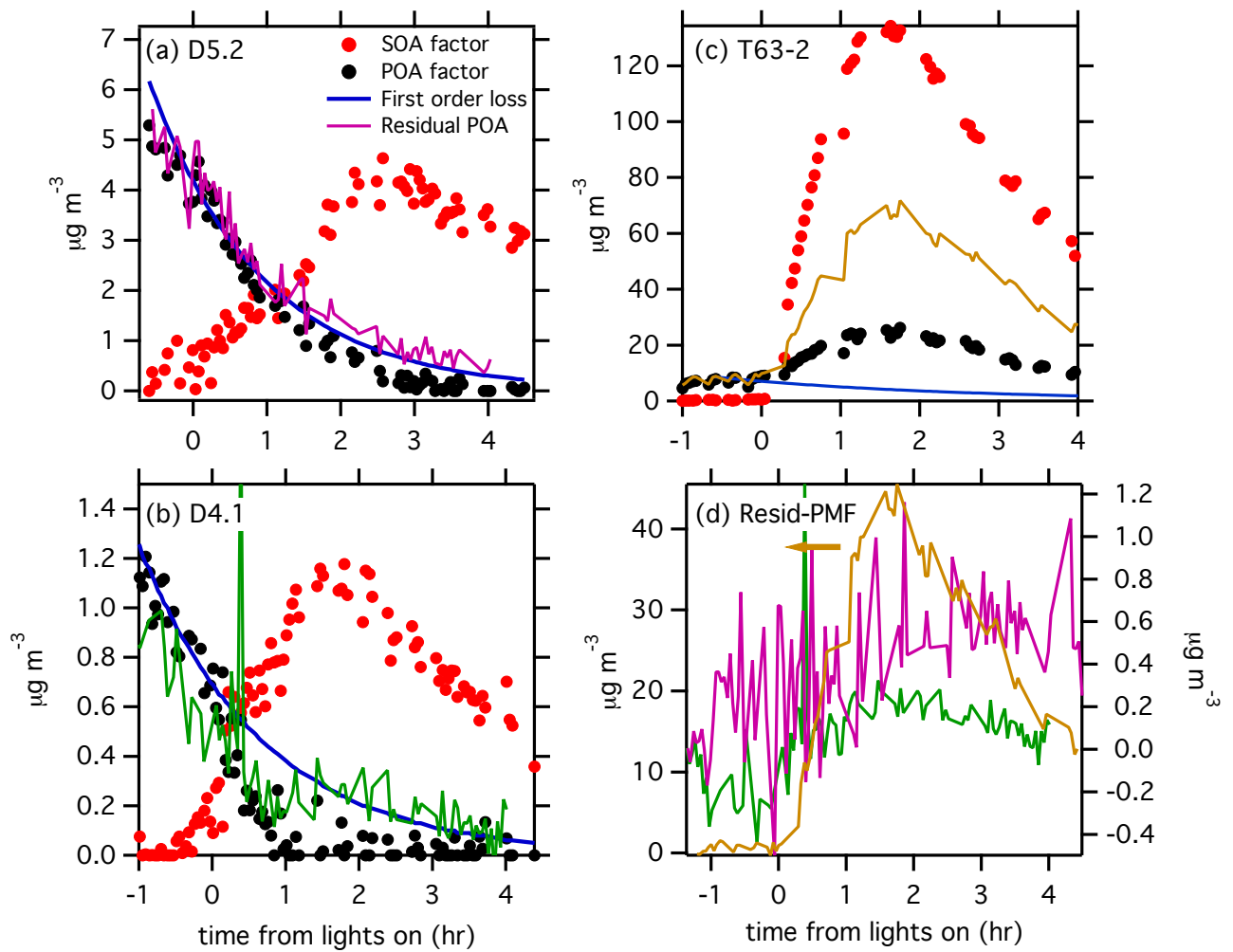

Figure 3. (a)-(c) Comparisons of PMF-derived POA (black symbols) and SOA (red symbols) concentrations to assumed first-order POA loss (blue line) and the POA concentration determined by the residual method. POA determined by the residual method is color-coded: purple for experiment D5.2 (a), green for D4.1 (b), and brown for T63-2 (c). The SOA concentration in (c) is the sum of SOA 1 and SOA 2. The difference between POA concentrations determined by the residual method and PMF is shown in (d). The residual method consistently overpredicts POA concentrations relative to PMF.

POA factor: (1) experiments where the POA factor followed first-order loss; (2) experiments where the POA concentration increased because of partitioning forcing POA vapors into the condensed phase with increasing $\mathrm{C}_{\mathrm{OA}}$; (3) experiments where the POA evaporated completely; and (4) experiments where POA initially evaporated after the start of photooxidation, but later increased because of partitioning. Each of these cases is described below.

The first class of experiments, when POA seemingly follows first-order loss to the chamber walls, includes all experiments with gasoline vehicles and experiments with the diesel vehicle D5. One example of this type of experiment is shown in Fig. 1, and a second example (experiment D5.2) is shown in Fig. 3a. As noted in Sect. 3.1.1, in these experiments the traditional definition of SOA - i.e., assuming that POA was a conserved tracer lost to the chamber walls with first-order kinetics - produced a reasonable SOA-POA split. Combined partitioning and kinetic analysis via Eqs. (1) and (2) indicates that for these experiments POA evaporation induced by increasing chamber temperature and consumption of POA vapors is almost perfectly balanced by additional POA condensation due to $\mathrm{C}_{\mathrm{OA}}$ increases from SOA formation. Each effect is relatively small - an increase in chamber temperature of $5{ }^{\circ} \mathrm{C}$ only induces a $6 \%$ loss of POA mass via evaporation, and a $5-10 \mu \mathrm{g} \mathrm{m}^{3}$ increase in $\mathrm{C}_{\mathrm{OA}}$ causes a $6-$ $9 \%$ increase in POA concentration - but on the whole these effects balance in nearly all of the gasoline and diesel vehicle experiments.

The second class of experiments, when POA mass concentrations increase, include all of the gas-turbine idle load experiments with the exception of experiment T63-1. Figure $3 \mathrm{c}$ shows an example for experiment T63-2. In these experiments, the large increase in $\mathrm{C}_{\mathrm{OA}}$ due to SOA formation dominates POA partitioning, and causes additional vapors to condense. Calculations with Eqs. (1) and (2) verify this conclusion. For these experiments, assuming that POA follows a first-order loss rate underestimates the POA concentration, and therefore overestimates SOA production.

The third class of experiments, when POA evaporates completely, includes two experiments with vehicle D4 (Fig. 3b). Before the start of photooxidation $(t<0)$, the POA factor followed a first-order wall loss rate. After the start of photooxidation at $t=0$, the POA factor disappeared completely within $1 \mathrm{~h}$. POA evaporation was caused by the consumption of organic vapors that were in phase equilibrium with the POA prior to oxidation and a $5{ }^{\circ} \mathrm{C}$ increase 
in chamber temperature. The increase in $\mathrm{COA}_{\mathrm{OA}}$ due to SOA formation was insufficient to counteract POA losses. Equations (1) and (2) fail to predict the complete POA evaporation of these experiments. This may be the result of a small fraction of the organic mass being in the condensed phase (May et al., 2012) at the start of photooxidation, which can enhance fractional particle-phase mass loss. Particle mass loss increases rapidly for cases when less than $25 \%$ of the low-volatility organic mass is in the condensed phase. This is the case for experiments with vehicle D4, when approximately $20 \%$ of the total low-volatility organic emissions were present in the condensed phase at $t=0$ (May et al., 2013a). Vehicle D4 has lower emissions of both lowvolatility and volatile organic species, and a lower fraction of organic emissions as POA, than the other gasoline and diesel vehicles considered here. For vehicle D4, assuming that the POA follows a first-order loss rate overestimates the POA concentration, and therefore underestimates SOA formation.

The final class of experiments includes one experiment, T63-1 (Fig. 2), where the POA initially evaporates before rising again. The initial POA loss is driven by chemical consumption of POA vapors and a small fraction of lowvolatility organic species in the condensed phase, as is the case for experiments with vehicle D4. The subsequent increase in POA concentration is a result of the large increase in $\mathrm{C}_{\mathrm{OA}}$ due to SOA formation.

\subsubsection{Comparison of PMF to the residual method}

The color-coded lines in Fig. 3a-c show the POA concentration determined using the residual method with $m / z 57$ as the POA tracer. For the diesel vehicle experiment shown in Fig. 3a, the POA concentration determined by the residual agrees well with the assumed first-order loss of POA. For experiment D5.2 (Fig. 3b) the residual method overestimates the POA concentration for $t>0$ and does not predict complete POA evaporation. In the case shown in Fig. 3c, the residual method overpredicts the POA concentration by as much as a factor of 3. This is due to the presence of $m / z 57$ in the SOA mass spectrum, which is erroneously assigned as POA by the residual method.

Figure $3 \mathrm{~d}$ shows the difference (residual-PMF) in POA concentrations determined by PMF and the residual method for the experiments shown in Fig. 3a-c. In each case, the residual method predicts more suspended POA mass than PMF at the end of photooxidation $(t=3 \mathrm{~h})$, with varying degrees of difference over the course of each experiment. The magnitude of the difference is variable: for the two diesel experiments shown in Fig. 3 the absolute difference between residual and PMF POA is less than $1 \mu \mathrm{g} \mathrm{m}^{-3}$, though the fractional difference can be large because of low POA concentrations. For the gas-turbine experiment shown in Fig. 3c, the difference between residual and PMF determined POA is as much as $42 \mu \mathrm{g} \mathrm{m}^{-3}$, and is still $25 \mu \mathrm{g} \mathrm{m}^{-3}$ at the completion of photooxidation. Performing wall loss corrections on these data would only exacerbate these differences.

Table 1 shows the maximum difference between the residual and PMF-derived suspended (non-wall corrected) POA mass concentrations. For all but one experiment (CFM562), the residual method overpredicts POA concentrations relative to PMF. In many cases for gasoline and diesel experiments the difference in absolute POA concentration determined by the residual method and PMF is small, approximately $0.5-1 \mu \mathrm{g} \mathrm{m}^{-3}$; however this typically represents an overestimation of $>80 \%$ relative to PMF. For the gasturbine experiments the residual method consistently overestimates POA concentrations, often by more than $100 \%$.

Overall we conclude that the residual method is a useful screening tool for these types of dilute exhaust SOA formation experiments. It performs reasonably well when POA concentrations follow first-order wall loss (e.g., no POA evaporation or additional condensation) and the SOA has little or no $m / z 57$ in its mass spectrum. Unfortunately these conditions are almost impossible to determine a priori, unless there is a very large increase in $\mathrm{C}_{\mathrm{OA}}$ that would indicate additional POA condensation, and ultimately we recommend the use of PMF to determine the exact POA-SOA split.

\subsection{Mass spectra of PMF factors}

\subsubsection{Gasoline and diesel vehicles}

Figure 4 shows the mass spectra of the POA and SOA factors for the experiment shown in Fig. 1. The POA mass spectrum is indicative of a large contribution of reduced $\left(\mathrm{C}_{\mathrm{x}} \mathrm{H}_{\mathrm{y}}\right)$ hydrocarbon species. $m / z 43\left(f_{43}=0.104\right)$ is the most abundant ion in the mass spectrum, and the series of $\mathrm{C}_{n} \mathrm{H}_{2 n+1}$ ( $m / z$ 43, 57, etc.) and $\mathrm{C}_{n} \mathrm{H}_{2 n-1}(\mathrm{~m} / z 41,55$, etc.) are evident. The mass spectrum of the SOA factor indicates substantial oxygen. $m / z, 44\left(f_{44}=0.103\right)$ is the largest peak, consistent with significant oxidation. Reduced peaks such as $m / z 57$ are depleted $\left(f_{57}=0\right)$. The mass spectrum of the SOA factor shown in Fig. 4a is similar to the SOA determined in pureSOA experiments; an example SOA mass spectrum is shown in Fig. S2b in the Supplement for experiment LEV2-1.2.

Table 1 lists each of the experiments considered here, and indicates whether or not PMF was used to deconvolve the AMS data (i.e., whether or not POA was present in the chamber after filling). Eight of the gasoline and diesel vehicle experiments listed in Table 1 did not require PMF. Seven of these experiments were pure-SOA experiments where no POA was present. One experiment (LEV1-6.3) had POA present, but no SOA was formed. The lack of SOA formation in this experiment was confirmed both by wall-lossbased mass analysis and by PMF. For experiments that used PMF, Table 1 also indicates the number of factors used in the solution. Seven of the eight experiments that required PMF analysis used a 2-factor solution with distinct POA and SOA factors, such as the case described above for experiment 


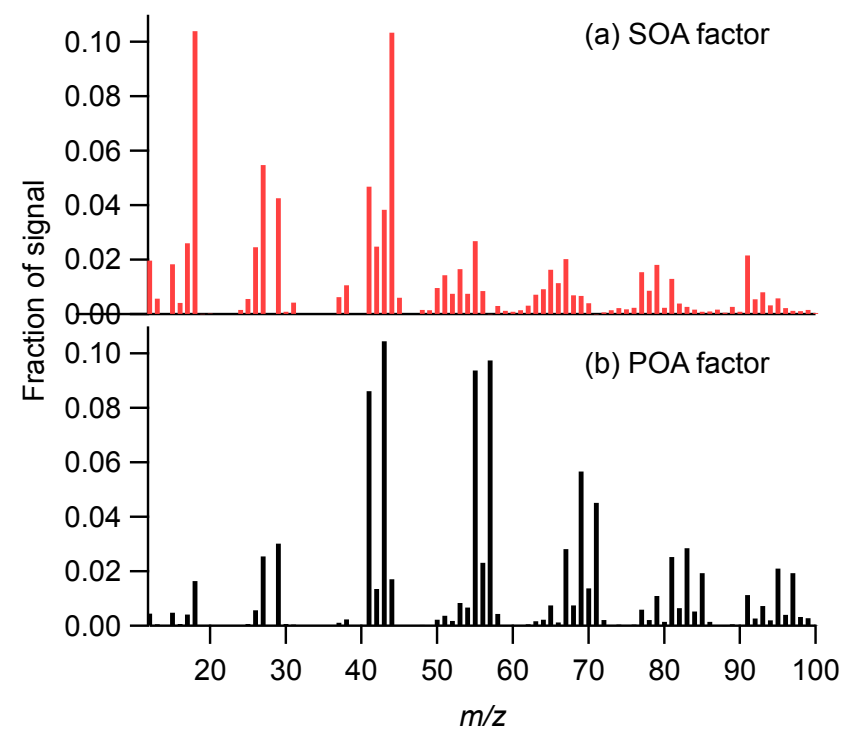

Figure 4. Mass spectra of the PMF factors for (a) SOA and (b) POA for the experiment shown in Fig. 1. The POA factor is dominated by reduced ions $\mathrm{C}_{\mathrm{x}} \mathrm{H}_{\mathrm{y}}, \mathrm{m} / z, 44$ is the largest ion in the SOA mass spectrum and $m / z 43$ is the largest ion in the POA mass spectrum.

LEV1-5.2. Figure 5d shows the average SOA mass spectrum across all of the gasoline experiments; this MS is used for comparisons to diesel SOA and ambient OOA factors below.

For one experiment (LEV1-6.1), a third PMF factor was required. A high nitrate SOA factor $\left(f_{30}=0.48\right.$, Fig. S6 in the Supplement) appeared immediately after the onset of photooxidation. The nitrate SOA factor contributed $>50 \%$ of the SOA mass for the first hour of photooxidation, but was quickly eclipsed by a more typical SOA factor, with a mass spectrum similar to Fig. $4 \mathrm{a}$, for $t>1.5 \mathrm{~h}$. By the end of the photooxidation portion of the experiment, the nitrate SOA factor contributed $\sim 20 \%$ of the suspended SOA mass. The discussion of experiment LEV1-6.1 below considers only the POA and non-nitrate SOA factors.

Figure 5a shows the POA factor for vehicle D5, which is from model year 2001 and does not have any exhaust after treatment. The mass spectrum has high abundances of the $\mathrm{C}_{n} \mathrm{H}_{2 n+1}$ and $\mathrm{C}_{n} \mathrm{H}_{2 n-1}$ series of ions, and $m / z 41,43,55$, and 57 are the most abundant ions in the mass spectrum. The POA mass spectrum from vehicle D5 exhibits a strong correlation to the average gasoline POA mass spectrum (Fig. 5g), suggesting a similar pathway for POA generation in these vehicles. Overall, the D5 and gasoline POA mass spectra are typical of primary combustion emissions, perhaps with the evaporation of lubricating oil (Sonntag et al., 2012; Worton et al., 2014) being the dominant source of POA.

Figure $5 \mathrm{~b}$ shows the POA mass spectrum for vehicle D4, a 2005 model year vehicle equipped with a diesel oxidation catalyst (DOC). It has both a high abundance of $m / z 44$ $\left(f_{44}=0.1\right)$ and the characteristic $\mathrm{C}_{n} \mathrm{H}_{2 n+1}$ and $\mathrm{C}_{n} \mathrm{H}_{2 n-1}$ series of ions typical of diesel POA. With the exception of
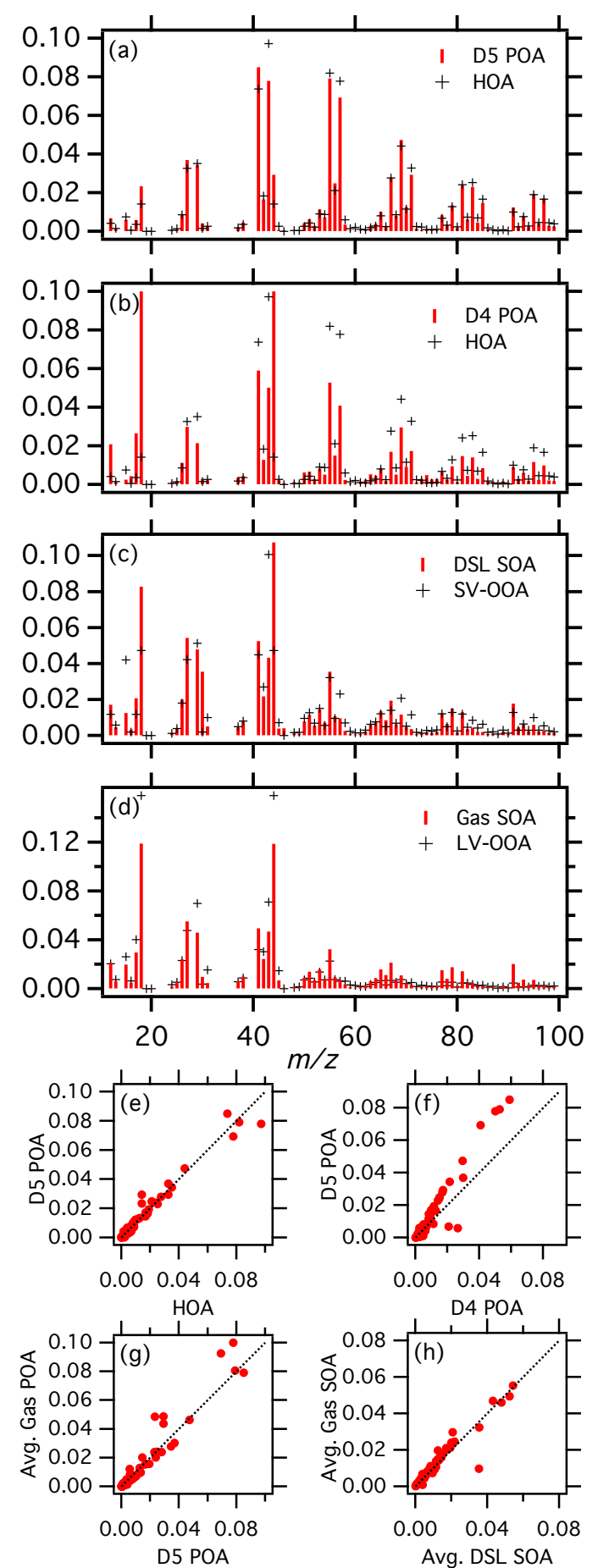

Figure 5. Mass spectra of POA emissions from vehicles D5 (a) and D4 (b) are shown and compared to ambient HOA. The average diesel SOA factor mass spectrum (c) is compared to the average ambient SV-OOA mass spectrum, and the average gasoline SOA (d) is compared to ambient LV-OOA. The scatter plots in (e)-(h) provide further comparisons of the mass spectra in (a)-(d). The dashed lines in (e)-(h) are the $1: 1$ line. 
the high $f_{44}$ (and $f_{18}$, which is set equal to $f_{44}$ in the fragmentation table), the mass spectra of the POA from D4 and D5 are highly correlated (Fig. 5f). Chirico et al. (2010) observed similar POA from a DOC-equipped passenger car. Specifically, they reported elevated abundances of oxygencontaining ions superimposed on top of a typical diesel POA backbone. The D4 POA mass spectrum is suggestive of lubricating oil emissions that become partially oxidized in the DOC.

The high $f_{44}$ in the D4 POA mass spectrum is not the result of errors in subtracting gas-phase $\mathrm{CO}_{2}$ from the $m / z 44$ signal in the AMS. All of the experiments described here adjusted the default $\mathrm{CO}_{2}$ value in the fragmentation table ( $370 \mathrm{ppm}$ ) based on the measured $\mathrm{CO}_{2}$ concentration in the smog chamber. $\mathrm{CO}_{2}$ concentrations in the chamber ranged between 600 and $900 \mathrm{ppm}$ for the gasoline and diesel experiments, and were not systematically different for the experiments with vehicle D4. A similar method of subtractive $\mathrm{CO}_{2}$ correction was recently validated by Collier and Zhang (2013) for much higher $\mathrm{CO}_{2}$ concentrations ( $>1,000 \mathrm{ppm}$ ).

Figure $5 \mathrm{c}$ shows the average mass spectrum for the diesel SOA factors. $m / z 44\left(f_{44}=0.107\right)$ is the most abundant ion in the mass spectrum, and reduced peaks such as $\mathrm{m} / z 57$ $\left(f_{57}=0.009\right)$ are depleted. SOA factors for vehicles D4 and D5 are nearly identical, suggesting that any differences in emissions and/or POA composition due to the presence of the DOC do not affect SOA composition. PTR-MS data indicate that the emissions of SOA-forming VOCs such as toluene and xylene isomers are lower for vehicle D4 than D5, but the relative abundances of these species (e.g., toluene/benzene ratios) are approximately constant. This suggests that SOA formed from the exhaust of vehicles D4 and D5 should have similar composition and AMS mass spectra.

Figure 5h shows that the average SOA mass spectra for the diesel and gasoline vehicles are similar. The largest difference between the mass spectra occurs at $m / z 30$ - for diesel SOA $f_{30}$ was 0.035 , whereas for gasoline vehicles $f_{30}$ $<0.01$. The similarity between gasoline and diesel exhaust SOA is interesting because the emissions of SOA precursors from the two types of engines are different, with diesel engines having a lower emission rate of SOA precursors, but also emitting compounds of lower volatility (May et al., 2014; Schauer et al., 1999, 2002). The similarity between gasoline and diesel SOA may be a result of similar emissions (e.g., reduced hydrocarbons) reacting under similar conditions of $\mathrm{VOC}: \mathrm{NO}_{\mathrm{x}}$ and $\mathrm{OH}$ concentration, independent of the volatility of the SOA precursors. Future experiments will be required to further probe this hypothesis.

\subsubsection{Gas-turbine experiments}

Figure 6 shows the mass spectra for the three PMF factors determined for experiment T63-1 shown in Fig. 2. The mass spectrum of the POA factor is shown in Fig. 6a. The most abundant peak is $m / z 55\left(f_{55}=0.10\right)$, and the series
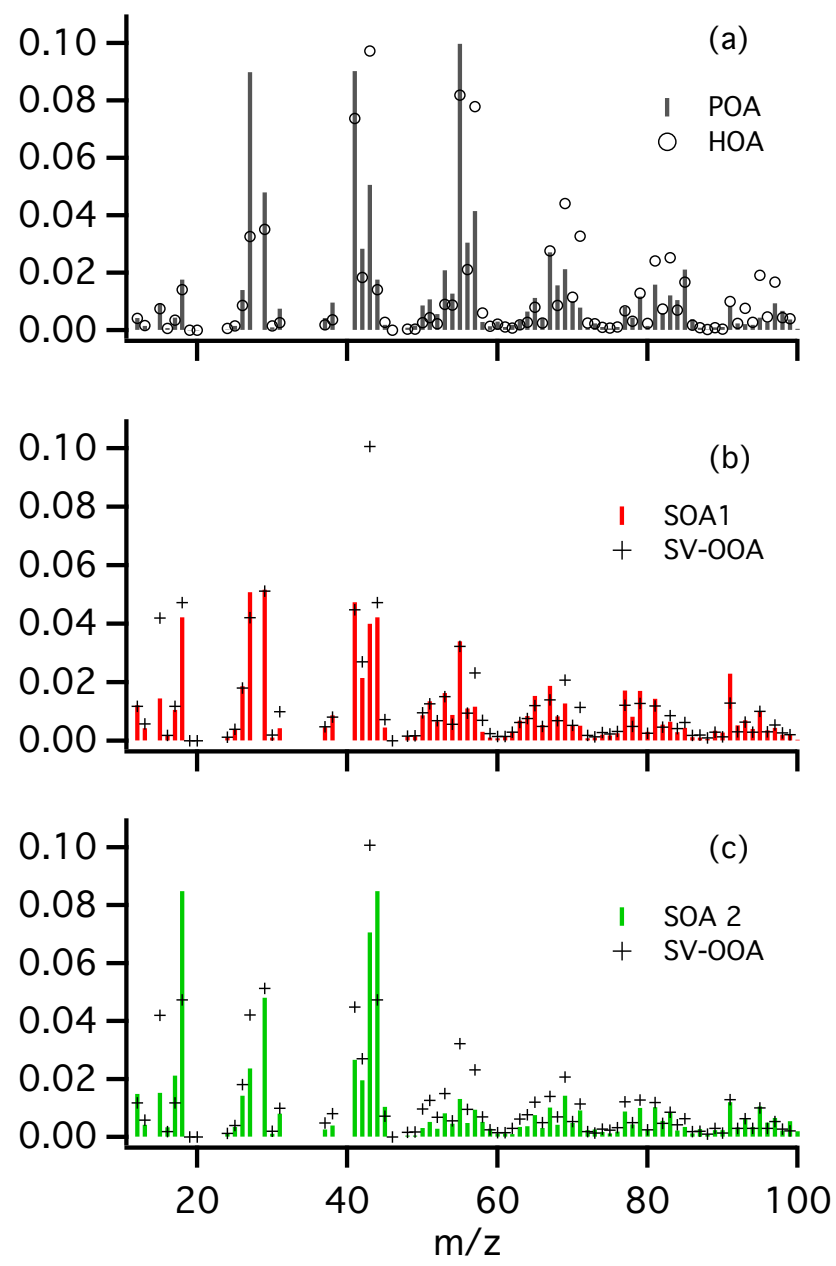

Figure 6. PMF-derived $\mathrm{OA}$ factors for the experiment shown in Fig. 2. POA factor (a), SOA 1 factor (b), and the SOA 2 (c) factor are shown along with comparisons to ambient HOA and SV-OOA factors.

of $\mathrm{C}_{n} \mathrm{H}_{2 n-1}$ peaks $(m / z, 27,41,55)$ are all larger than the corresponding $\mathrm{C}_{n} \mathrm{H}_{2 n+1}$ peaks $(m / z 29,43,57)$. This is indicative of reduced, hydrocarbon-like species with cyclic moieties. $m / z 44$ is also present in the POA mass spectrum $\left(f_{44}=0.017\right)$. These mass spectral features are consistent with previously reported measurements of the POA mass spectrum from the CFM56 engine (Presto et al., 2011) and the lubricating oil used in the T63.

The mass spectra for SOA 1 and SOA 2 are shown in Fig. $6 \mathrm{~b}$ and c, respectively. SOA 2 is the more oxidized factor, with $f_{44}=0.085$, compared to $f_{44}=0.042$ for SOA 1 . $\mathrm{m} / z 44$ is the most abundant peak in the SOA 2 mass spectrum, whereas $m / z 29$ is the most abundant peak in SOA 1 . SOA 2 also has a higher $f_{43}$ (0.071 versus 0.04$)$. While the quadrupole AMS used here is not capable of separating the $\mathrm{C}_{3} \mathrm{H}_{7}^{+}$and $\mathrm{C}_{2} \mathrm{H}_{3} \mathrm{O}^{+}$ions present at $m / z 43$, it is likely that the $m / z 43$ signal for SOA 2 is dominated by the oxidized 
$\mathrm{C}_{2} \mathrm{H}_{3} \mathrm{O}^{+}$ion, consistent with mildly oxidized OA (Kroll et al., 2009).

\subsubsection{Constraining PMF solutions with mass spectra of POA factors}

A unique aspect of applying PMF to the experiments presented here is that the POA mass spectrum is constrained by the design of the experiment. As long as there is no chemical processing of the POA during the pre-oxidation period of each experiment, we are able to directly measure the POA mass concentration and mass spectrum and compare these measurements to the PMF POA factors. Indeed, the direct measurement of the POA mass spectrum is used in the residual method to constrain POA decay (Sage et al., 2008).

Therefore the POA mass spectrum offers an additional constraint on the PMF solution for these experiments that is not available when analyzing ambient data sets. Figure 7 shows comparisons of measured and PMF-derived POA mass spectra for three separate experiments using a gasoline vehicle (Fig. 7a, experiment LEV1-6.2), a diesel vehicle (Fig. 7b, experiment D5.2), and a gas-turbine engine (Fig. 7c, experiment T63-2). The inset to each panel shows a scatter plot of the two mass spectra, and the black line is the $1: 1$ line.

The examples shown in Fig. 7 span the range of measurement versus PMF agreement in the POA mass spectrum. The gasoline vehicle experiment shows the poorest agreement between measured and PMF-derived POA mass spectra for any of the experiments considered here. The PMF-derived mass spectrum significantly overpredicts the abundances of $m / z 43,55$, and 57 by as much as $40 \%\left(f_{57 \text {, meas }}=0.072\right.$ versus $f_{57, \mathrm{PMF}}=0.102$ ). PMF also underpredicts $m / z 44$, which was unusually high in the POA for this experiment $\left(f_{44, \text { meas }}=0.065\right)$. Complete agreement between the measured and PMF-derived POA mass spectra was not achievable by adjusting FPEAK or by including more factors in the PMF solution. For example, the full range of $f_{57}$ for $-1 \leq$ FPEAK $\leq 1$ in the 2 -factor PMF solution for this experiment was $0.096-0.126$.

Figure $7 \mathrm{~b}$ and $\mathrm{c}$ show much better, and much more typical, agreement between measured and PMF-derived POA mass spectra. For experiment D5.2 shown in Fig. 7b, PMF overpredicts $f_{41}$ by $0.015, f_{55}$ and $f_{57}$ by $\leq 0.01$, and underpredicts $f_{69}$ by 0.004 . The maximum deviation at any $\mathrm{m} / z$ for experiment T63-4 (Fig. 4c) is 0.005 for $f_{41}$.

The agreement between measured and PMF-derived POA mass spectra was used as an evaluation tool to determine 2versus 3-factor PMF solutions, especially for the idle load gas-turbine engine experiments that exhibited large increases in $\mathrm{C}_{\mathrm{OA}}$. Figure $7 \mathrm{c}$ illustrates excellent agreement between the measured POA and the PMF-derived POA factor for a 3 -factor solution for an experiment with the T63 engine. Figure 8 shows another case for experiment CFM56-2, and compares the measured POA to PMF-derived POA mass spec-
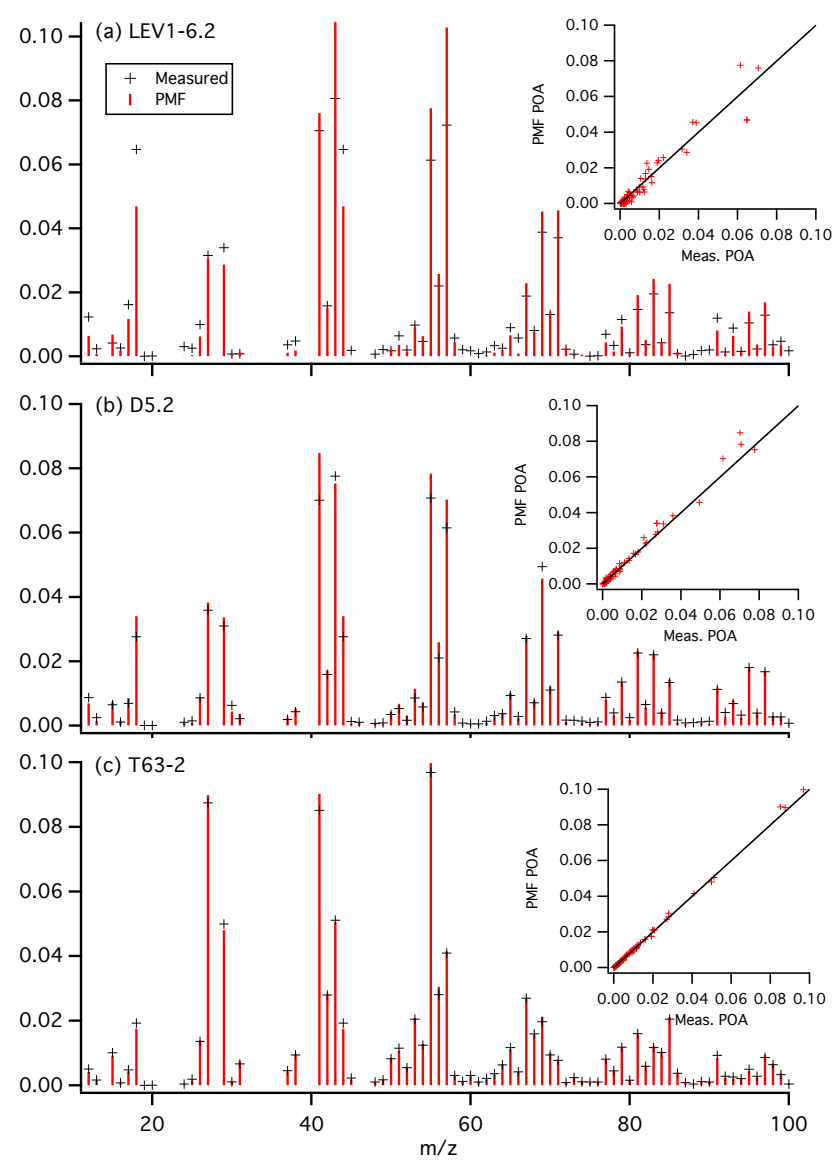

Figure 7. Comparisons of the mass spectra of PMF-derived POA factors (red sticks) to direct measurements of POA conducted prior to photooxidation (symbols) up to $m / z$ 100. Insets show scatter plots of the mass spectra, and the black line is the $1: 1$ line. Comparisons are presented for experiments LEV1-6.2 (a), D5.2 (b), and T63-2 (c).

tra for 2- and 3-factor solutions. As with the cases shown in Fig. 7, POA factors from both the 2- and 3-factor PMF solutions overpredict $f_{41}$ and $f_{55}$, and underpredict $f_{44}$. However, the overprediction is larger for the 3 -factor solution, and overall there is poorer agreement between the measured and PMF-derived POA mass spectra for the 3-factor solution. The experiment shown in Fig. 8 is representative of the other $4 \%$ idle load experiments with the CFM56 engine. Thus, 2-factor PMF solutions were used for these experiments.

\subsection{Comparison of PMF-derived MS to ambient factors}

\subsubsection{Gasoline and diesel vehicles}

Figure 5 shows that the mass spectra for gasoline and uncontrolled diesel (vehicle D5) POA agree well with the average ambient HOA factor reported by $\mathrm{Ng}$ et al. (2011b). The HOA factor has more mass at $m / z 43\left(f_{43}=0.097\right)$ and 57 than uncontrolled diesel POA (Fig. 5a); however the 


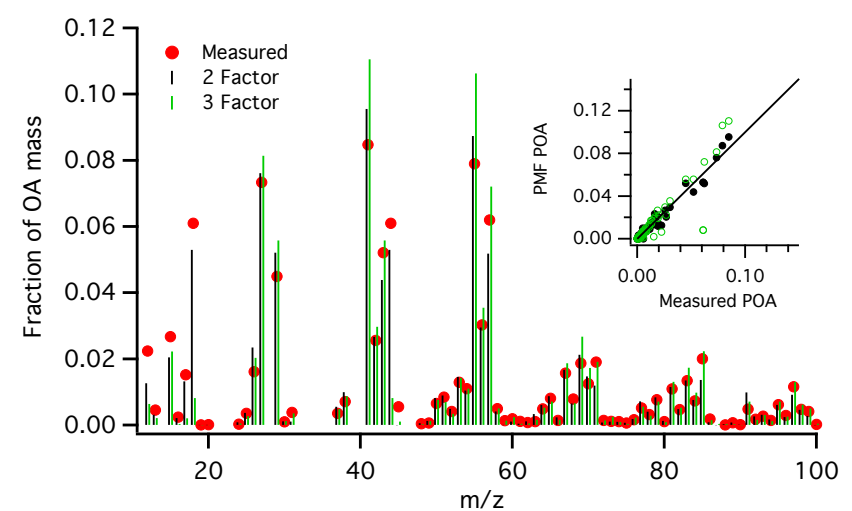

Figure 8. Comparison of the measured POA for experiment CFM56-2 (symbols) to the POA factors determined by 2-factor (black) and 3-factor (green) PMF solutions. The inset shows scatter plots of the mass spectra, and the black line is the $1: 1$ line. There is better agreement between the measured POA and the 2-factor solution for this experiment.

overall agreement between the POA and HOA mass spectra is good. The strong similarities between the two mass spectra are also apparent in the scatter plot of the two mass spectra (Fig. 5e), and in the angle ( $\theta$ ) between the two spectra. The angle between the two mass spectra is computed by treating each mass spectrum as a vector (Kostenidou et al., 2013; Kostenidou et al., 2009). The angle between the D5 POA and HOA mass spectra is $12^{\circ}$, indicating strong agreement. There is a similarly high correlation between the gasoline vehicle POA mass spectrum and the ambient HOA factor $\left(R^{2}=0.98\right)$.

The POA from vehicle D4, with elevated abundance of $f_{44}$, matches poorly with ambient HOA (Fig. 5 b). The differences between the POA mass spectrum for vehicle D4 and the ambient HOA factor suggests that vehicles without DOC dominate the on-road diesel fleet. This is indeed the case. Equipping a large fraction of the diesel fleet with DOC might therefore change the canonical spectrum of ambient HOA to include more oxygenated ions.

Figure 5 also compares the gasoline and diesel SOA factors to the average SV-OOA and LV-OOA factors presented by $\mathrm{Ng}$ et al. (2011b). Figure 5c compares the average diesel SOA mass spectrum to ambient SV-OOA. Overall there is poor absolute agreement between the two mass spectra. The angle between the two mass spectra is $>30^{\circ}$. The diesel SOA has a higher $f_{44}$ and lower $f_{43}$ than SV-OOA. The diesel SOA factor also has higher abundances of several $\mathrm{m} / z$ (55, 67 , and 91) that can all appear in either a reduced $\left(\mathrm{C}_{\mathrm{x}} \mathrm{H}_{\mathrm{y}}^{+}\right)$or oxidized $\left(\mathrm{C}_{\mathrm{x}} \mathrm{H}_{\mathrm{y}} \mathrm{O}^{+}\right)$form.

Figure $5 \mathrm{~d}$ compares the average gasoline SOA factor to the ambient LV-OOA mass spectrum. Overall, LV-OOA is more oxidized than the SOA formed in these experiments and has a higher abundance of oxidized ions, including $m / z 29$, 43 , and 44 . The average gasoline SOA mass spectrum has a
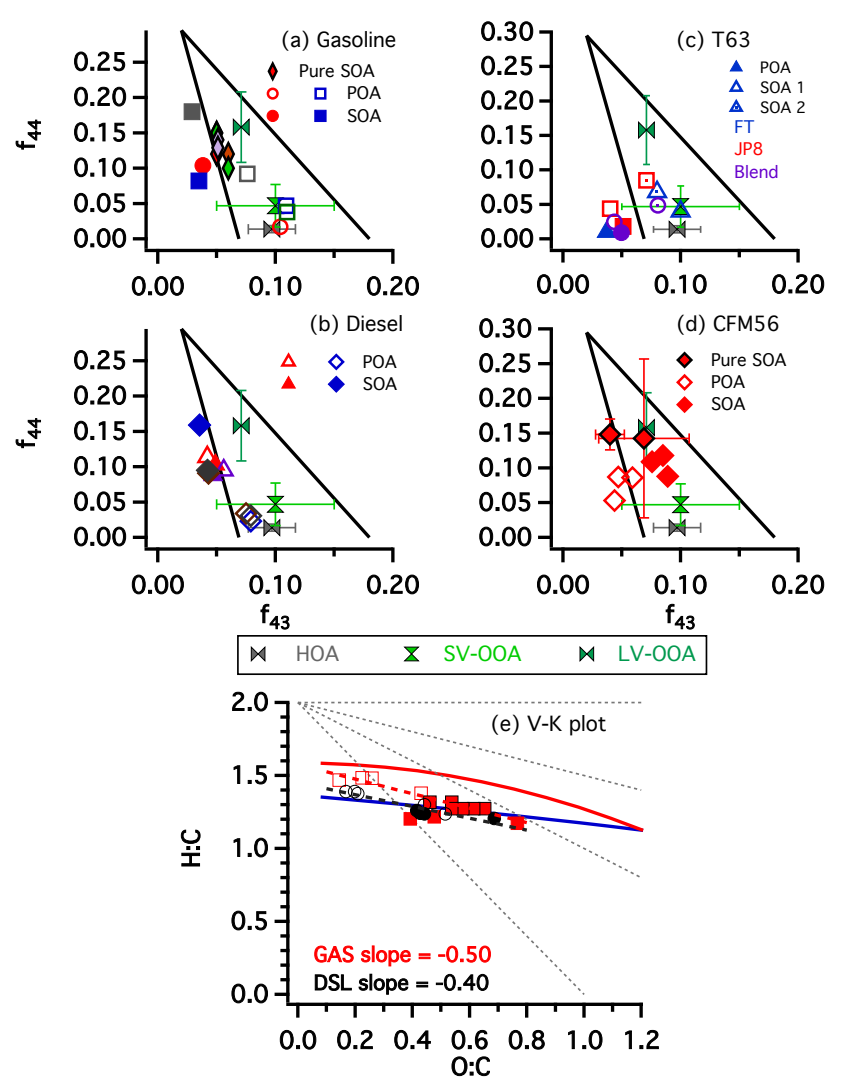

Figure 9. (a)-(d) show triangle plots for gasoline vehicle, diesel vehicle, and gas-turbine engine experiments. Average ambient HOA, SV-OOA, and LV-OOA are also shown, and the error bars indicate the range in $f_{44}$ and $f_{43}$ reported by $\mathrm{Ng}$ et al. (2011b). (e) shows a van Krevelen plot of the gasoline and diesel data from (a) and (b), with POA shown as open symbols and SOA as closed symbols. $\mathrm{F}_{44}$ and $f_{43}$ are converted to $\mathrm{O}: \mathrm{C}$ (Aiken et al., 2008) and $\mathrm{H}: \mathrm{C}(\mathrm{Ng}$ et al., 2011a) using published relationships.

higher abundance of $m / z 55$ and nearly every ion larger than $m / z 60$, suggestive of less chemical processing.

Strong correlations between the mass spectra for the experimental SOA and ambient OOA factors are not necessarily expected, whereas the high correlation between the mass spectra of the POA factor and published HOA are expected. Ambient HOA is thought to be dominated by fresh combustion emissions, especially from internal combustion engines, and therefore should have a mass spectrum similar to the vehicle POA observed here. The OOA factors, which represent ambient SOA, are a combination of SOA from many sources, including dilute exhaust, biogenic emissions, and other sources. The SV-OOA and LV-OOA mass spectra used in Fig. 5 are averages compiled over multiple studies in different cities. The mass spectra of the specific SV- and LVOOA factors determined from these studies are highly variable from site to site ( $\mathrm{Ng}$ et al., 2011b), perhaps indicating strong local influences of, for example, local SOA precursor emissions on the OOA observed in a particular location. 
Figure 9 offers another comparison of the experimental POA and SOA factors to ambient factors using triangle plots (Ng et al., 2010, 2011a), plots of $f_{44}$ versus $f_{43}$. Average ambient HOA, SV-OOA, and LV-OOA from Ng et al. (2011b) are also included in the triangle plots. $\mathrm{Ng}$ et al. (2011b) presented ranges of $f_{44}$ and $f_{43}$ for these factors from various field studies; the error bars represent these ranges.

As noted above, the POA from the gasoline vehicles and from vehicle D5 all resemble ambient $\mathrm{HOA}$, and this is reflected in the triangle plots in Fig. 9a and b. The POA from these experiments cluster near $f_{43} \sim 0.1$ and $f_{44} \sim 0.01$, near the average ambient HOA factor presented by $\mathrm{Ng}$ et al. (2011b). There are two exceptions: one is vehicle D4, which is described above and has high $f_{44}(\sim 0.1)$. The second exception is for experiment LEV1-6.2, which has a higher abundance of $m / z 44\left(f_{44}=0.047\right)$ and a lower abundance of $m / z, 43$ than either the ambient HOA factor or the POA factors from the other gasoline vehicles. The reason for this is not clear, as the POA from the other two experiments with the same vehicle (LEV1-6.1, LEV1-6.3) did not exhibit high $f_{44}$. In general, vehicle LEV1-6 was classified as a "high emitter" and had difficulties with its emissions control system. This vehicle also had the greatest experiment-to-experiment variability of fuel economy, $\mathrm{PM}$, and $\mathrm{NO}_{\mathrm{x}}$ emissions of any of the vehicles in the test fleet (May et al., 2014). The POA from experiment LEV1-6.2 may be another manifestation of this variability.

The SOA from the pure-SOA gasoline-powered vehicle experiments are shown as diamonds with black borders in Fig. 9a. There is remarkable consistency in both $f_{43}(0.06-$ $0.07)$ and $f_{44}(0.1-0.14$, with most vehicles between 0.12 and 0.14) for these vehicles, independent of control technology (LEV-1 versus LEV-2). The total, wall-loss-corrected amount of SOA formed in these experiments was also consistent from vehicle to vehicle $\left(9.6 \pm 2.9 \mu \mathrm{g} \mathrm{m}^{-3}\right)$.

The SOA factors for gasoline vehicles determined from PMF analysis are shown as solid symbols with no border in Fig. 9a. The SOA factors for these experiments have lower $f_{43}$ than the pure-SOA experiments, and a similar range of $f_{44}$. The diesel SOA factors from both vehicle D4 and D5 occupy a similar range of $f_{44}$ and $f_{43}$ to the gasoline SOA factors.

Overall, the SOA from the gasoline and diesel vehicles occupy a space in $f_{44}$ that is intermediate between ambient SVOOA and LV-OOA. $f_{44}$ in the SOA from these vehicles is approximately 0.1 , which lies at the lower bound of $f_{44}$ for LV-OOA reported by Ng et al. (2011b), but slightly above the upper bound of $f_{44}$ for SV-OOA. The SOA from the gas and diesel vehicles has lower $f_{43}(\sim 0.05)$ than ambient LV-OOA, and is on the lower edge of the range of $f_{43}$ observed for SVOOA. The SOA mass spectra cluster along the left edge of the triangular space defined by ambient OA measurements, suggesting that these SOA mass spectra, while exhibiting poor absolute agreement with ambient SV- and LV-OOA fac- tors, do fall within the bounds of OOA typically observed in the atmosphere.

\subsubsection{Gas-turbine engines}

Figure 6 compares the POA and SOA factors from experiment T63-1 to ambient HOA and SV-OOA factors. As noted in section 3.3.2, POA from gas-turbine engines has a lower abundance of $\mathrm{C}_{n} \mathrm{H}_{2 n+1}$ peaks and a higher abundance of $\mathrm{C}_{n} \mathrm{H}_{2 n-1}$ peaks than ambient HOA. It therefore matches poorly with ambient HOA $\left(\theta=29^{\circ}\right)$. This is echoed in the triangle plots for the CFM (Fig. 9d) and T63 (Fig. 9c) engines. The POA from these sources has lower $f_{43}$ than ambient HOA. POA emissions from the T63 engine have similar $f_{44}$ to ambient HOA $(\sim 0.01)$, and POA from the CFM56 has higher $f_{44}(\sim 0.07)$ than ambient HOA.

The T63 engine was tested with three different fuels: petroleum-based JP8, a synthetic FT fuel, and a 50:50 volume blend of FT and JP8. The POA mass spectrum is nearly identical for each of these three fuels $\left(\theta=6-15^{\circ}\right)$. We previously observed similar agreement between the aerosol mass spectra of POA emitted from the CFM56 engine and atomized samples of the lubricating oil used in that engine (Presto et al., 2011). The AMS data and PMF analysis therefore suggest that the source of POA from the T63 engine is independent of fuel composition, and supports the hypothesis that lubricating oil is the dominant contributor to POA emitted from gas-turbine engines (Drozd et al., 2012).

Figure $6 \mathrm{~b}$ compares the SOA 1 factor for experiment T631 to the ambient SV-OOA mass spectrum. The SOA 1 factor compares poorly with SV-OOA, and notably has significantly less mass at $m / z 43\left(f_{43}=0.04\right.$ versus 0.11 for SV-OOA). The low $f_{43}$ in the SOA 1 factor may be coupled to the low $f_{43}$ in the POA factor. The SOA-forming vapors co-emitted with the POA presumably have similar composition to the POA, and are therefore likely enriched in moieties that generate $\mathrm{C}_{n} \mathrm{H}_{2 n-1}^{+}$ions (e.g., $m / z$ 41) rather than $\mathrm{C}_{n} \mathrm{H}_{2 n+1}^{+}$ions (e.g., $m / z$ 43). Thus, SOA formed from the mild oxidation of these vapors could also be expected to be depleted in $m / z 43$ compared to ambient SV-OOA, especially if the $m / z 43$ signal in SOA 1 is dominated by $\mathrm{C}_{3} \mathrm{H}_{7}^{+}$instead of $\mathrm{C}_{2} \mathrm{H}_{3} \mathrm{O}^{+}$.

When placed in triangle space, the SOA 1 factors for the JP8 and blended-fuel experiments fall closer to the POA than to ambient OOA factors. However, the POA and SOA 1 mass spectra share few similarities and have a wide angle $\left(29^{\circ}\right)$ between them. We hypothesize that the SOA 1 factor in the JP8 and blended-fuel experiments is driven largely by partitioning, and represents early-stage oxidation products that are forced into the condensed phase at high $\mathrm{C}_{\mathrm{OA}}$ $\left(>\sim 100 \mu \mathrm{g} \mathrm{m}^{-3}\right.$ ) but would otherwise not be observed if the experiments were conducted at lower concentrations.

The SOA 1 factor for the FT experiments, on the other hand, closely resembles ambient SV-OOA. Figure 9c compares the two factors in triangle space, and a full mass spectral comparison is provided in Fig. S7 of the Supplement. 
There are two potential explanations for the differences in SOA 1 mass spectra between the FT experiments and the JP8 and blended-fuel experiments: partitioning and chemistry. We expect that partitioning is the more important effect. Experiments with FT fuel had a factor of 10-100 lower $\mathrm{C}_{\mathrm{OA}}$ than experiments with JP8 and blended fuel (Miracolo et al., 2012). In the latter cases, the observed OA concentration exceeded $100 \mu \mathrm{g} \mathrm{m}^{-3}$ on several occasions, and this could drive substantial partitioning of POA and mildly oxidized vapors into the condensed phase. SOA chemistry may also play a role in differentiating the SOA 1 factors for FT experiments. SOA precursor emissions, especially of aromatic compounds, were significantly higher for JP8 and blendedfuel experiments (Drozd et al., 2012; Miracolo et al., 2012).

Figure $6 \mathrm{c}$ shows that the SOA 2 factor for experiment T631 , while more oxidized than the SOA 1 factor, has poor absolute agreement with the average ambient SV-OOA mass spectrum. SV-OOA has higher $f_{43}$ and $f_{57}$ than the SOA 2 factor; as with the SOA 1 factor these differences may be driven by the composition of the SOA-forming vapors favoring $m / z 41$ and 55. The SOA 2 factor is more oxidized than SV-OOA, and has a higher $f_{44}$, but is less oxidized than ambient LV-OOA. Figure 9c compares the SOA 2 factors in triangle space. SOA 2 factors for all three fuels fall within the range of ambient SV-OOA.

SOA from the CFM56 experiments have similar $f_{44}$ to the SOA factors from the gasoline and diesel experiments, and lie between SV-OOA and LV-OOA in the triangle plot (Fig. 9d). One significant difference between the CFM56 SOA factors and the gasoline and diesel SOA factors is higher $f_{43}$ in the CFM56 SOA $(\sim 0.08)$. The $f_{43}$ in the CFM56 SOA is therefore similar to $f_{43}$ for ambient SV- and LV-OOA.

\subsection{Chemical evolution of $\mathrm{OA}$}

Figure 9e translates the gasoline and diesel POA and SOA into van Krevelen space using the relationships of $f_{44}$ to $\mathrm{O}: \mathrm{C}$ (Aiken et al., 2008) and $f_{43}$ to $\mathrm{H}: \mathrm{C}$ (Ng et al., 2011a). The gasoline data fall along a line with a slope of -0.50 , and the diesel data have a slope of -0.40 . This suggests that SOA formation chemistry in these experiments is a combination of carboxylic acid and alcohol/peroxide formation ( $\mathrm{Ng}$ et al., 2011a; Heald et al., 2010). These van Krevelen slopes are similar to that reported by $\mathrm{Ng}$ et al. (2011a) for ambient OOA factors. They are also similar to the range of slopes observed by Lambe et al. (2012) for the photooxidation of n-alkanes, diesel fuel, and crude oil in a flow tube reactor. The most relevant comparison might be to Heald et al. (2010), who reported a slightly higher slope of approximately -1 for ambient data (including both HOA and OOA). Overall, the van Krevelen plot suggests that the SOA chemistry observed in the gasoline and diesel vehicle smog chamber experiments is atmospherically relevant.
In the gasoline and diesel experiments we observe a decoupling of the chemistry and the final aerosol mass spectra as informed by the AMS data. The chemical mechanisms governing SOA formation in these experiments and in the atmosphere - e.g., carboxylic acid and alcohol/peroxide formation - are a function of several factors, including the mixture of oxidants present (e.g., ratio of $\mathrm{OH}: \mathrm{O}_{3}$ ), the role and extent of photolysis, and the specific chemical reaction mechanisms, which are governed in part by the VOC: $\mathrm{NO}_{\mathrm{x}}$ ratio. The SOA mass spectra are a result of these chemical mechanisms, but are also dependent upon the SOA-forming VOCs present in the smog chamber during photooxidation. Thus, while we observe chemical processing consistent with ambient observations, the resultant SOA mass spectra are variable, and not identical to published ambient mass spectra.

However, we should not expect to produce SOA that is identical to SV-OOA or LV-OOA in the laboratory. As noted by $\mathrm{Ng}$ et al. (2011b), there is substantial variability in the SV-OOA and LV-OOA factors determined from ambient data sets, with SV-OOA exhibiting more variability than LVOOA. $f_{43}$ for ambient SV-OOA spans a range from 0.05 to 0.15 , suggesting that the composition of SV-OOA is highly variable from city to city. Since SV-OOA is thought to represent "fresh" SOA, it is quite likely that SV-OOA composition in a particular city is a consequence of the specific emissions in that city - e.g., one city may have more gasoline vehicle emissions, whereas another may have more biogenic emissions. The data presented in Figs. 5 and 9 indicate that while the gasoline and diesel SOA factors determined here do not match precisely with average ambient SV-OOA or LV-OOA mass spectra, they do fall into the general range of ambient OOA factors. For example, the SOA factors are contained inside or on the edges of the triangular space in Fig. 9.

The gas-turbine experiments are not converted to van Krevelen space. The trajectory of the POA-to-SOA conversion, using the SOA 2 factor for T63 experiments, would yield a positive slope in van Krevelen space. Such a slope is not explainable by known oxidation mechanisms for ambient organic chemistry. A line of zero slope would correspond to alcohol/peroxide formation, which we would expect under the low- $\mathrm{NO}_{\mathrm{x}}$ conditions in the idle load experiments. Deviations from that slope in this analysis could result from errors in converting unit mass resolution AMS data to $\mathrm{O} / \mathrm{C}$ and $\mathrm{H} / \mathrm{C}$ ratios.

\section{Conclusions}

In this work, we present AMS analysis of OA from smog chamber experiments using dilute exhaust from gasoline vehicles, diesel vehicles, and gas-turbine engines. The experiments presented here capture approximately $2-5 \mathrm{~h}$ of photooxidation under ambient $\mathrm{OH}$ concentrations. PMF is used to deconvolve POA and SOA factors when substantial POA is present in the dilute exhaust. The results presented here 
indicate that the gasoline and diesel vehicle experiments can be explained either as pure-SOA formation with no POA present or by using a 2-factor PMF solution with one POA factor and one SOA factor. Gas-turbine experiments with one engine (CFM56) can be explained with 2-factor PMF solutions, but experiments with the other engine (T63) require 3 -factor solutions that contain one POA factor and two SOA factors.

POA factors determined via PMF are verified through both the standard set of PMF diagnostics such as Q/ $Q_{\exp }$ and the residual of the PMF solution, as well as by comparing the measured POA mass spectrum to the PMF-derived mass spectrum of the POA factor. Direct comparisons between measured and PMF-derived POA mass spectra are an advantage of these types of dilute exhaust smog chamber experiments, where the POA is directly observed prior to photooxidation.

The time series of POA concentration and the POASOA split determined by PMF was compared to the residual method of Sage et al. (2008) using $\mathrm{m} / z 57$ as the POA tracer. For the gasoline and diesel experiments, which had relatively low $\mathrm{C}_{\mathrm{OA}}$ and a small abundance of $f_{57}$ in the PMF-derived SOA mass spectrum, the residual method and PMF generally agree to within $1 \mu \mathrm{g} \mathrm{m}^{-3}$ on the concentration of suspended (non-wall corrected) POA. While the absolute agreement between PMF and the residual method in these experiments is generally good, the difference between the two methods constitutes a large fraction, often $>80 \%$, of the PMF-determined POA mass. The residual method performs very poorly for the gas-turbine engine experiments, in large part because these experiments had large $\mathrm{C}_{\mathrm{OA}}$ increases during oxidation, and the residual method overapportions POA mass. We determine that while the residual method can be a useful tool for determining the POA-SOA split in these sorts of dilute exhaust SOA experiments, we recommend that future studies rely on PMF to apportion POA and SOA mass.

POA factors determined from PMF analysis of vehicular emissions are similar to the HOA factor derived from ambient data sets, and contain high abundances of the $\mathrm{C}_{n} \mathrm{H}_{2 n+1}$ and $\mathrm{C}_{n} \mathrm{H}_{2 n-1}$ series of ions ( $\mathrm{Ng}$ et al., 2010, 2011a). This is consistent with evaporated lubricating oil being a major source of ambient POA emissions. Vehicle D4 is the exception. The POA from this vehicle has a high $f_{44}$, though the $\mathrm{C}_{n} \mathrm{H}_{2 n+1}$ and $\mathrm{C}_{n} \mathrm{H}_{2 n-1}$ ions are still present. POA factors from gas-turbine engines have a higher abundance of $\mathrm{C}_{n} \mathrm{H}_{2 n-1}$ ions (e.g., $m / z 41,55$ ) than $\mathrm{C}_{n} \mathrm{H}_{2 n+1}$ ions, consistent with previous observations (Presto et al., 2011), and therefore do not have a strong correlation with ambient HOA. This is consistent with gasoline and diesel emissions, and not aircraft emissions, being major sources of ground-level POA in most urban areas.

Aerosol mass spectra of gasoline and diesel SOA cluster in an area of high $f_{44}(\sim 0.1)$ and low $f_{43}(\sim 0.05)$. The SOA factors from gasoline and diesel experiments are similar to each other; however the mass spectra of the SOA factors are not identical to published mass spectra of ambient OOA factors (SV-OOA or LV-OOA) or published mass spectra of SOA formed from traditional SOA precursors such as singlering aromatic compounds. Nonetheless, SOA formed from gasoline and diesel exhaust falls between SV-OOA and LVOOA and within the triangular region of ambient OA measurements when plotted in an $f_{44}$ versus $f_{43}$ triangle plot. SOA factors from the gas-turbine experiments are similar to SV-OOA in $f_{44}$ versus $f_{43}$ triangle space (Fig. 9). The maximum $\mathrm{O}: \mathrm{C}$ ratio observed here is approximately 0.6 , consistent with less-oxidized SV-OOA (Ng et al., 2010, 2011a). Further oxidative processing is required to produce more oxidized LV-OOA (Ng et al., 2010, 2011a; Lambe et al., 2011).

Translation of the AMS data into van Krevelen space (Fig. 9e) provides information concerning the oxidation chemistry in the gasoline and diesel experiments. The slopes for gasoline and diesel exhaust oxidation in van Krevelen space are -0.50 and -0.40 . This suggests that SOA formation chemistry is a combination of carboxylic acid and alcohol/peroxide formation (Ng et al., 2011a; Heald et al., 2010), and is an indication that the photooxidation chemistry in the experiments presented here is atmospherically relevant. Ambient OA data, when plotted in van Krevelen space, exhibit slopes between -1 (Heald et al., 2010), indicative of chemistry dominated by carboxylic acid formation, and $-0.5(\mathrm{Ng}$ et al., 2011a), indicative of chemistry dominated by a mixture of acid formation and alcohol/peroxide formation.

\section{The Supplement related to this article is available online at doi:10.5194/acp-14-5015-2014-supplement.}

Acknowledgements. We thank Matti Maricq at Ford and Hector Maldonado at the California Air Resource Board for helping organize and lead the Linking Tailpipe-to-Ambient project. Funding was provided by the US Environmental Protection Agency National Center for Environmental Research (NCER) through the STAR program (R834554), the Coordinating Research Council through A74/E96, and by the US Department of Defense Strategic Environmental Research and Development Program (SERDP) under project WP-1626. The California Air Resources Board provided significant in-kind support, including vehicle recruitment, vehicle testing, and sample analysis. The views, opinions, and/or findings contained in this paper are those of the authors and should not be construed as an official position of the funding agencies.

Edited by: A. Laskin

\section{References}

Aiken, A. C., DeCarlo, P. F., and Jimenez, J. L.: Elemental analysis of organic species with electron ionization high-resolution mass spectrometry, Anal. Chem., 79, 8350-8358, 2007.

Aiken, A. C., DeCarlo, P. F., Kroll, J. H., Worsnop, D. R., Huffman, J. A., Docherty, K. S., Ulbrich, I. M., Mohr, C., Kimmel, 
J. R., Sueper, D., Sun, Y., Zhang, Q., Trimborn, A., Northway, M., Ziemann, P. J., Canagaratna, M. R., Onasch, T. B., Alfarra, M. R., Prevot, A. S. H., Dommen, J., Duplissy, J., Metzger, A., Baltensperger, U., and Jimenez, J. L.: O/C and OM/OC ratios of primary, secondary, and ambient organic aerosols with high-resolution time-of-flight aerosol mass spectrometry, Environ. Sci. Technol., 42, 4478-4485, 2008.

Aiken, A. C., Salcedo, D., Cubison, M. J., Huffman, J. A., DeCarlo, P. F., Ulbrich, I. M., Docherty, K. S., Sueper, D., Kimmel, J. R., Worsnop, D. R., Trimborn, A., Northway, M., Stone, E. A., Schauer, J. J., Volkamer, R. M., Fortner, E., de Foy, B., Wang, J., Laskin, A., Shutthanandan, V., Zheng, J., Zhang, R., Gaffney, J., Marley, N. A., Paredes-Miranda, G., Arnott, W. P., Molina, L. T., Sosa, G., and Jimenez, J. L.: Mexico City aerosol analysis during MILAGRO using high resolution aerosol mass spectrometry at the urban supersite (T0) - Part 1: Fine particle composition and organic source apportionment, Atmos. Chem. Phys., 9, 6633-6653, doi:10.5194/acp-9-6633-2009, 2009.

Allan, J. D., Delia, A. E., Coe, H., Bower, K. N., Alfarra, M. R., Jimenez, J. L., Middlebrook, A. M., Drewnick, F., Onasch, T. B., and Canagaratna, M. R.: A generalised method for the extraction of chemically resolved mass spectra from Aerodyne aerosol mass spectrometer data, J. Aerosol Sci., 35, 909-922, 2004.

Anderson, B. E., Chen, G., and Blake, D. R.: Hydrocarbon emissions from a modern commercial airliner, Atmos. Environ., 40, 3601-3612, 2006.

Atkinson, R. and Arey, J.: Atmospheric degradation of volatile organic compounds, Chem. Rev., 103, 4605-4638, 2003.

Canagaratna, M. R., Jayne, J. T., Ghertner, D. A., Herndon, S., Shi, Q., Jimenez, J. L., Silva, P. J., Williams, P., Lanni, T., Drewnick, F., Demerjian, K. L., Kolb, C. E., and Worsnop, D. R.: Chase studies of particulate emissions from in-use New York City vehicles, Aerosol Sci. Technol., 38, 555-573, 2004.

Canagaratna, M. R., Jayne, J. T., Jimenez, J. L., Allan, J. D., Alfarra, M. R., Zhang, Q., Onasch, T. B., Drewnick, F., Coe, H., Middlebrook, A., Delia, A., Williams, L. R., Trimborn, A. M., Northway, M. J., DeCarlo, P. F., Kold, C. E., Davidovits, P., and Worsnop, D. R.: Chemical and microphysical characterization of ambient aerosols with the Aerodyne aerosol mass spectrometer, Mass Spectrom. Rev., 26, 185-222, 2007.

Chirico, R., DeCarlo, P. F., Heringa, M. F., Tritscher, T., Richter, R., Prevot, A. S. H., Dommen, J., Weingartner, E., Wehrle, G., Gysel, M., Laborde, M., and Baltensperger, U.: Impact of aftertreatment devices on primary emissions and secondary organic aerosol formation potential from in-use diesel vehicles: Results from smog chamber experiments, Atmos. Chem. Phys., 10, 11545-11563, doi:10.5194/acp-10-11545-201, 2010.

Collier, S., and Zhang, Q.: Gas-phase $\mathrm{CO}_{2}$ subtraction for improved measurements of the organic aerosol mass concentration and oxidation degree by an aerosol mass spectrometer, Environ. Sci. Technol., 47, 14324-14331, doi:10.1021/es404024h, 2013.

Craven, J. S., Yee, L. D., Ng, N. L., Canagaratna, M. R., Loza, C. L., Schilling, K. A., Yatavelli, R. L. N., Thornton, J. A., Ziemann, P. J., Flagan, R. C., and Seinfeld, J. H.: Analysis of secondary organic aerosol formation and aging using positive matrix factorization of high-resolution aerosol mass spectra: application to the dodecane low-NO $\mathrm{NO}_{\mathrm{x}}$ system, Atmos. Chem. Phys., 12, 1179511817, doi:10.5194/acp-12-11795-2012, 2012.
Docherty, K. S., Wu, W., Lim, Y. B., and Ziemann, P. J.: Contributions of organic peroxides to secondary organic aerosol formed from reactions of monoterpenes with $\mathrm{O}_{3}$, Environ. Sci. Technol., 39, 4049-4059, 2005.

Docherty, K. S., Stone, E. A., Ulbrich, I. M., DeCarlo, P. F., Snyder, D. C., Schauer, J. J., Peltier, R. E., Weber, R. J., Murphy, S. M., Seinfeld, J. H., Grover, B. D., Eatough, D. J., and Jimenez, J. L.: Apportionment of primary and secondary organic aerosols in sourthern California during the 2005 study of organic aerosols in Riverside (SOAR-1), Environ. Sci. Technol., 42, 7655-7662, 2008.

Donahue, N. M., Robinson, A. L., Stanier, C. O., and Pandis, S. N.: Coupled partitioning, dilution, and chemical aging of semivolatile organics, Environ. Sci. Technol., 40, 2635-2643, 2006.

Donahue, N. M., Robinson, A. L., and Pandis, S. N.: Atmospheric organic particulate matter: From smoke to secondary organic aerosol, Atmos. Environ., 43, 94-106, 2009.

Donahue, N. M., Epstein, S. A., Pandis, S. N., and Robinson, A. L.: A two-dimensional volatility basis set: 1. Organic-aerosol mixing thermodynamics, Atmos. Chem. Phys., 11, 3303-3318, doi:10.5194/acp-11-3303-2011, 2011.

Donahue, N. M., Kroll, J. H., Pandis, S. N., and Robinson, A. L.: A two-dimensional volatility basis set -Part 2: Diagnostics of organic-aerosol evolution, Atmos. Chem. Phys., 12, 615-634, doi:10.5194/acp-12-615-2012, 2012.

Drozd, G. T., Miracolo, M. A., Presto, A. A., Lipsky, E. M., Riemer, D. D., Corporan, E., and Robinson, A. L.: Particulate and organic vapor emissions from an in-use helicopter engine, Energy Fuels, 26, 4756-4766, doi:10.1021/ef300651t, 2012.

Farmer, D. K., Matsunaga, A., Docherty, K. S., Surratt, J. D., Seinfeld, J. H., Ziemann, P. J., and Jimenez, J. L.: Response of an aerosol mass spectrometer to organonitrates and organosulfates and implications for atmospheric chemistry, Proc. Natl. Acad. Sci., 107, 6670-6675, 2010.

Gordon, T. D., Presto, A. A., Nguyen, N. T., Robertson, W. H., Na, K., Sahay, K. N., Zhang, M., Maddox, C., Rieger, P., Chattopadhyay, S., Maldonado, H., Maricq, M. M., and Robinson, A. L.: Secondary organic aerosol production from diesel vehicle exhaust: impact of aftertreatment, fuel chemistry and driving cycle, Atmos. Chem. Phys., 14, 4643-4659, doi:10.5194/acp-14-46432014, 2014a.

Gordon, T. D., Presto, A. A., May, A. A., Nguyen, N. T., Lipsky, E. M., Donahue, N. M., Gutierrez, A., Zhang, M., Maddox, C., Rieger, P., Chattopadhyay, S., Maldonado, H., Maricq, M. M., and Robinson, A. L.: Secondary organic aerosol formation exceeds primary particulate matter emissions for lightduty gasoline vehicles, Atmos. Chem. Phys., 14, 4661-4678, doi:10.5194/acp-14-4661-2014, 2014b.

Grieshop, A. P., Donahue, N. M., and Robinson, A. L.: Laboratory investigation of photochemical oxidation of organic aerosol from wood fires 2: analysis of aerosol mass spectrometer data, Atmos. Chem. Phys., 9, 2227-2240, doi:10.5194/acp-9-2227-2009, 2009a.

Grieshop, A. P., Logue, J. M., Donahue, N. M., and Robinson, A. L.: Laboratory investigation of photochemical oxidation of organic aerosol from wood fires 1: measurement and simulation of organic aerosol evolution, Atmos. Chem. Phys., 9, 1263-1277, doi:10.5194/acp-9-1263-2009, 2009b. 
Heald, C. L., Kroll, J. H., Jimenez, J. L., Docherty, K. S., DeCarlo, P. F., Aiken, A. C., Chen, Q., Martin, S. T., Farmer, D. K., and Artaxo, P.: A simplified description of the evolution of organic aerosol compositoin in the atmosphere, Geophys. Res. Lett., 37, L08803, doi:10.1029/2010GL042737, 2010.

Hennigan, C. J., Miracolo, M. A., Engelhart, G. J., May, A. A., Presto, A. A., Lee, T., Sullivan, A. P., McMeeking, G. R., Coe, H., Wold, C. E., Hao, W.-M., Gilman, J. B., Kuster, W. C., de Gouw, J., Schichtel, B. A., Collett, J. L., Kreidenweis, S. M., and Robinson, A. L.: Chemical and physical transformations of organic aerosol from the photo-oxidation of open biomass burning emissions in an environmental chamber, Atmos. Chem. Phys., 11, 7669-7686, doi:10.5194/acp-11-7669-2011, 2011.

Heringa, M. F., DeCarlo, P. F., Chirico, R., Tritscher, T., Dommen, J., Weingartner, E., Richter, R., Wehrle, G., Prévôt, A. S. H., and Baltensperger, U.: Investigations of primary and secondary particulate matter of different wood combustion appliances with a high-resolution time-of-flight aerosol mass spectrometer, Atmos. Chem. Phys., 11, 5945-5957, doi:10.5194/acp-11-59452011, 2011.

Hildebrandt, L., Donahue, N. M., and Panids, S. N.: High formation of secondary organic aerosol from the photo-oxidation of toluene, Atmos. Chem. Phys., 9, 2973-2986, doi:10.5194/acp-92973-2009, 2009.

Huffman, J. A., Docherty, K. S., Aiken, A. C., Cubison, M. J., U1brich, I. M., DeCarlo, P. F., Sueper, D., Jayne, J. T., Worsnop, D. R., Ziemann, P. J., and Jimenez, J. L.: Chemically-resolved aerosol volatility measurements from two megacity field studies, Atmos. Chem. Phys., 9, 7161-7182, doi:10.5194/acp-9-71612009, 2009.

Jayne, J. T., Leard, D. C., Zhang, X. F., Davidovits, P., Smith, K. A., Kolb, C. E., and Worsnop, D. R.: Development of an aerosol mass spectrometer for size and composition analysis of submicron particles, Aerosol Sci. Technol., 33, 49-70, 2000.

Kanakidou, M., Seinfeld, J. H., Pandis, S. N., Barnes, I., Dentener, F. J., Facchini, M. C., Van Dingenen, R., Ervens, B., Nenes, A., Nielsen, C. J., Swietlicki, E., Putaud, J. P., Balkanski, Y., Fuzzi, S., Horth, J., Moortgat, G. K., Winterhalter, R., Myhre, C. E. L., Tsigaridis, K., Vignati, E., Stephanou, E. G., and Wilson, J.: Organic aerosol and global climate modelling: A review, Atmos. Chem. Phys., 5, 1053-1123, doi:10.5194/acp-5-1053-2005, 2005.

Kostenidou, E., Lee, B.-H., Engelhart, G. J., Pierce, J. R., and Pandis, S. N.: Mass spectra deconvolution of low, medium, and high volatility biogenic organic aerosol, Environ. Sci. Technol., 43, 4884-4889, doi:10.1021/es803676g, 2009.

Kostenidou, E., Kaltsonoudis, C., Tsiflikiotou, M., Louvaris, E., Russell, L. M., and Pandis, S. N.: Burning of olive tree branches: a major organic aerosol source in the Mediterranean, Atmos. Chem. Phys., 13, 8797-8811, doi:10.5194/acp-13-8797-2013, 2013.

Kroll, J. H., Smith, J. D., Che, D. L., Kessler, S. H., Worsnop, D. R., and Wilson, K. R.: Measurement of fragmentation and functionalization pathways in the heterogeneous oxidation of oxidized organic aerosol, Phys. Chem. Chem. Phys., 11, 8005-8014, 2009.

Lambe, A. T., Onasch, T. B., Massoli, P., Croasdale, D. R., Wright, J. P., Ahern, A. T., Williams, L. R., Worsnop, D. R., Brune, W. H., and Davidovits, P.: Laboratory studies of the chemical composition and cloud condensation nuclei $(\mathrm{CCN})$ activity of secondary organic aerosol (SOA) and oxidized primary organic aerosol (OPOA), Atmos. Chem. Phys., 11, 8913-8928, doi:10.5194/acp11-8913-2011, 2011.

Lambe, A. T., Onasch, T. B., Croasdale, D. R., Wright, J. P., Martin, A. T., Franklin, J. P., Massoli, P., Kroll, J. H., Canagaratna, M. R., Brune, W. H., Worsnop, D. R., and Davidovits, P.: Transitions from functionalization to fragmentation reactions of laboratory secondary organic aerosol (SOA) generated from the $\mathrm{OH}$ oxidation of alkane precursors, Environ. Sci. Technol., 46, 5430-5437, 2012.

Lanz, V. A., Alfarra, M. R., Baltensperger, U., Buchmann, B., Hueglin, C., and Prevot, A. S. H.: Source apportionment of submircon organic aerosols at an urban site by factor analytical modelling of aerosol mass spectra, Atmos. Chem. Phys., 7, 15031522, doi:10.5194/acp-7-1503-2007, 2007.

Massoli, P., Fortner, E. C., Canagaratna, M. R., Williams, L. R., Zhang, Q., Sun, Y., Schwab, J. J., Trimborn, A., Onasch, T. B., Demerjian, K. L., Kolb, C. E., Worsnop, D. R., and Jayne, J. T.: Pollution gradients and chemical characterization of particulate matter from vehicular traffic near major roadways: Results from the 2009 Queens College air quality study in NYC, Aerosol Sci. Technol., 46, 1201-1218, doi:10.1080/02786826.2012.701784, 2012.

May, A. A., Saleh, R., Hennigan, C. J., Donahue, N. M., and Robinson, A. L.: Volatility of organic molecular markers used for source apportionment analysis: Measurements and implications for atmospheric lifetime, Environ. Sci. Technol., 46, 1243512444, 2012.

May, A. A., Presto, A. A., Gordon, T. D., Nguyen, N. T., Hennigan, C. J., and Robinson, A. L.: Gas-particle partitioning of primary organic aerosol emissions: (2) diesel vehicles, Environ. Sci. Technol., 47, 8288-8296, doi:10.1021/es400782j, 2013a.

May, A. A., Presto, A. A., Nguyen, N. T., Hennigan, C. J., Gordon, T. D., and Robinson, A. L.: Gas-particle partitioning of primary organic aerosol emissions: (1) gasoline vehicle exhaust, Atmos. Environ., 77, 128-139, doi:10.1016/j.atmosenv.2013.04.060, 2013b.

May, A. A., Nguyen, N. T., Presto, A. A., Gordon, T. D., Lipsky, E. M., Karve, M., Guitierrez, A., Robertson, W. H., Zhang, M., Chang, O., Chen, S., Cicero-Fernandez, P., Fuentes, M., Huang, S.-M., Ling, R., Long, J., Maddox, C., Massetti, J., McCauley, E., Na, K., Pang, Y., Rieger, P., Sax, T., Truong, T., Vo, T., Chattopadhyay, S., Maldonado, H., Maricq, M. M., and Robinson, A. L.: Primary gas and PM emissions from light and heavy duty vehicles, Atmos. Environ., 88, 247-260, doi:10.1016/j.atmosenv.2014.01.046, 2014.

Miracolo, M. A., Presto, A. A., Lambe, A. T., Hennigan, C. J., Donahue, N. M., Kroll, J. H., Worsnop, D. R., and Robinson, A. L.: Secondary organic aerosol formation from low-volatility organic vapors in motor vehicle emissions, Environ. Sci. Technol., 44, 1638-1643, 2010.

Miracolo, M. A., Hennigan, C. J., Ranjan, M., Nguyen, N. T., Gordon, T. D., Lipsky, E. M., Presto, A. A., Donahue, N. M., and Robinson, A. L.: Secondary aerosol formation from photochemical aging of aircraft exhaust in a smog chamber, Atmos. Chem. Phys., 11, 4135-4147, doi:10.5194/acp-11-4135-2011, 2011.

Miracolo, M. A., Drozd, G. T., Jathar, S. H., Presto, A. A., Lipsky, E. M., Corporan, E., and Robinson, A. L.: Fuel composition and secondary organic aerosol formation: Gas-turbine exhaust and al- 
ternative aviation fuels, Environ. Sci. Technol., 46, 8493-8501, 2012.

Ng, N. L., Chhabra, P. S., Chan, A. W. H., Surratt, J. D., Kroll, J. H., Kwan, A. J., McCabe, D. C., Wennberg, P. O., Sorooshian, A., Murphy, S. M., Dalleska, N. F., Flagan, R. C., and Seinfeld, J. H.: Effect of $\mathrm{NO}_{\mathrm{x}}$ level on secondary organic aerosol (SOA) formation from the photooxidation of terpenes, Atmos. Chem. Phys., 7, 5159-5174, doi:10.5194/acp-7-5159-2007, 2007.

Ng, N. L., Canagaratna, M. R., Zhang, Q., Jimenez, J. L., Tian, J., Ulbrich, I. M., Kroll, J. H., Docherty, K. S., Chhabra, P. S., Bahreini, R., Murphy, S. M., Seinfeld, J. H., Hildebrandt, L., Donahue, N. M., DeCarlo, P. F., Lanz, V. A., Prevot, A. S. H., Dinar, E., Rudich, Y., and Worsnop, D. R.: Organic aerosol components observed in northern hemisphere datasets from aerosol mass spectrometry, Atmos. Chem. Phys., 10, 46254641, doi:10.5194/acp-10-4625-201, 2010.

Ng, N. L., Canagaratna, M. R., Jimenez, J. L., Chhabra, P. S., Seinfeld, J. H., and Worsnop, D. R.: Changes in organic aerosol composition with aging inferred from aerosol mass spectra, Atmos. Chem. Phys., 11, 6465-6474, doi:10.5194/acp-11-64652011, 2011a.

Ng, N. L., Canagaratna, M. R., Jimenez, J. L., Zhang, Q., Ulbrich, I. M., and Worsnop, D. R.: Real-time methods for estimating organic component mass concentrations from aerosol mass spectrometer data, Environ. Sci. Technol., 45, 910-916, doi:10.1021/es102951k, 2011b.

Nordin, E. Z., Eriksson, A. C., Roldin, P., Nilsson, P. T., Carlsson, J. E., Kajos, M. K., Hellen, H., Wittborn, C., Rissler, J., Londahl, J., Swietlicki, E., Svenningsson, B., Bohgard, M., Kulmala, M., Hallquist, M., and Pagels, J.: Secondary organic aerosol formation from idling gasoline passenger vehicle emissions investigated in a smog chamber, Atmos. Chem. Phys., 13, 6101-6116, doi:10.5194/acp-13-6101-2013, 2013.

Paatero, P.: Least squares formulation of robust non-negative factor analysis, Chemometrics and Intelligent Laboratory Systems, 37 , 23-35, 1997.

Paatero, P. and Tapper, U.: Positive matrix factorization: A nonnegative factor model with optimal utilization of error estimates of data values, Environmetrics, 5, 111-126, 1994.

Platt, S. M., El Haddad, I., Zardini, A. A., Clairotte, M., Astorga, C., Wolf, R., Slowik, J. G., Temime-Roussel, B., Marchand, N., Ježek, I., Drinovec, L., Močnik, G., Möhler, O., Richter, R., Barmet, P., Bianchi, F., Baltensperger, U., and Prévôt, A. S. H.: Secondary organic aerosol formation from gasoline vehicle emissions in a new mobile environmental reaction chamber, Atmos. Chem. Phys., 13, 9141-9158, doi:10.5194/acp-13-91412013, 2013.

Presto, A. A., Huff Hartz, K. E., and Donahue, N. M.: Secondary organic aerosol formation from terpene ozonolysis. 2. Effect of $\mathrm{NO}_{\mathrm{x}}$ concentration, Environ. Sci. Technol., 39, 7046-7054, 2005.

Presto, A. A., Nguyen, N. T., Ranjan, M., Reeder, A. J., Lipsky, E. M., Hennigan, C. J., Miracolo, M. A., Riemer, D. D., and Robinson, A. L.: Fine particle and organic vapor emissions from staged tests of an in-use aircraft engine, Atmos. Environ., 45, 3603-3612, 2011.

Presto, A. A., Hennigan, C. J., Nguyen, N. T., and Robinson, A. L.: Determination of volatility distributions of primary organic aerosol emissions from internal combus- tion engines using thermal desorption gas chromatography mass spectrometry, Aerosol Sci. Technol., 46, 1129-1139, doi:10.1080/02786826.2012.700430, 2012.

Robinson, A. L., Donahue, N. M., Shrivastava, M. K., Weitkamp, E. A., Sage, A. M., Grieshop, A. P., Lane, T. E., Pierce, J. R., and Pandis, S. N.: Rethinking organic aerosols: Semivolatile emissions and photochemical aging, Science, 315, 1259-1262, 10.1126/science.1133061, 2007.

Sage, A. M., Weitkamp, E. A., Robinson, A. L., and Donahue, N. M.: Evolving mass spectra of the oxidized component of organic aerosol: Results from aerosol mass spectrometer analyses of aged diesel emissions, Atmos. Chem. Phys., 8, 1139-1152, doi:10.5194/acp-8-1139-2008, 2008.

Samy, A. and Zielinska, B.: Secondary organic aerosol production from modern diesel engines, Atmos. Chem. Phys., 10, 609-625, doi:10.5194/acp-10-609-2010, 2010.

Schauer, J. J., Kleeman, M. J., Cass, G. R., and Simoneit, B. R. T.: Measurement of emissions from air pollution sources. 2. $\mathrm{C} 1$ through $\mathrm{C} 30$ organic compounds from medium duty diesel trucks, Environ. Sci. Technol., 33, 1578-1587, 1999.

Schauer, J. J., Kleeman, M. J., Cass, G. R., and Simoneit, B. R. T.: Measurement of emissions from air pollution sources. 4. C1C32 organic compounds from gasoline-powered motor vehicles, Environ. Sci. Technol., 36, 567-575, 2002.

Sonntag, D. B., Bailey, C. R., Fulpert, C. R., and Baldauf, R. W.: Contribution of lubricating oil to particulate matter emissions from light-duty gasoline vehicles in Kansas City, Environ. Sci. Technol., 46, 4191-4199, 2012.

Spicer, C. W., Holdren, M. W., Smith, D. L., Hughes, D. P., and Smith, M. D.: Chemical composition of exhaust from aircraft turbine engines, J. Eng. Gas Turbines Power, 114, 111-115, 1992.

Sun, J., Zhang, Q., Canagaratna, M. R., Zhang, Y., Ng, N. L., Sun, Y., Jayne, J. T., Zhang, X., Zhang, X., and Worsnop, D. R.: Highly time- and size-resolved characterization of submicron aerosol particles in Beijing using an Aerodyne aerosol mass spectrometer, Atmos. Environ., 44, 131-140, 2010.

Sun, Y. L., Zhang, Q., Schwab, J. J., Yang, T., Ng, N. L., and Demerjian, K. L.: Factor analysis of combined organic and inorganic aerosol mass spectra from high resolution aerosol mass spectrometer measurements, Atmos. Chem. Phys., 12, 8537-8551, doi:10.5194/acp-12-8537-2012, 2012.

Ulbrich, I. M., Canagaratna, M., Zhang, Q., Worsnop, D. R., and Jimenez, J. L.: Interpretation of organic components from positive matrix factorization of aerosol mass spectrometric data, Atmos. Chem. Phys., 9, 2891-2918, doi:10.5194/acp-9-2891-2009, 2009.

Warren, B., Song, C., and Cocker, D. R.: Light intensity and light source influence on secondary organic aerosol formation for the $\mathrm{m}$-xylene/ $\mathrm{NO}_{\mathrm{x}}$ photooxidation system, Environ. Sci. Technol., 42, 5461-5466, 2008.

Weitkamp, E. A., Sage, A. M., Donahue, N. M., and Robinson, A. L.: Organic aerosol formation from photochemical oxidation of diesel exhaust in a smog chamber, Environ. Sci. Technol., 41, 6969-6975, 2007.

Wey, C. C., Anderson, B. E., Hudgins, C. H., Li-Jones, X., Winstead, E., Thornhill, L. K., Lobo, P., Hagen, D., Whitefield, P., Yelvington, P. E., Herndon, S. C., Onasch, T. B., Miake-Lye, R. C., Wormhoudt, J., Knighton, W. B., Howard, R., Bryant, D., Corporan, E., Moses, C., Holve, D., and Dodds, W.: Aircraft 
particle emissions experiment (APEX), NASA, Glenn Research Center, Cleveland, OH, 2006.

Worton, D. R., Isaacman, G., Gentner, D. R., Dallmann, T. R., Chan, A. W. H., Ruehl, C. R., Kirchstetter, T. W., Wilson, K. R., Harley, R. A., and Goldstein, A. H.: Lubricating oil dominates primary organic aerosol emissions from motor vehicles, Environ. Sci. Technol., 48, 3698-3706, doi:10.1021/es405375j, 2014.

Zhang, Q., Alfarra, M. R., Worsnop, D. R., Allan, J. D., Coe, H., Canagaratna, M. R., and Jimenez, J. L.: Deconvolution of hydrocarbon-like and oxygenated organic aerosols based on aerosol mass spectrometry, Environ. Sci. Technol., 39, 49384952, 2005.

Zhang, Q., Jimenez, J. L., Canagaratna, M. R., Allan, J. D., Coe, H., Ulbrich, I., Alfarra, M. R., Takami, A., Middlebrook, A. M., Sun, Y. L., Dzepina, K., Dunlea, E., Docherty, K., DeCarlo, P. F., Salcedo, D., Onasch, T., Jayne, J. T., Miyoshi, T., Shimono, A., Hatakeyama, S., Takegawa, N., Kondo, Y., Schneider, J., Drewnick, F., Borrmann, S., Weimer, S., Demerjian, K., Williams, P., Bower, K., Bahreini, R., Cottrell, L., Grffin, R. J., Rautiainen, J., Sun, J. Y., Zhang, Y. M., and Worsnop, D. R.: Ubiquity and dominance of oxygenated species in organic aerosols in anthropogenically-influenced northern hemisphere midlatitudes, Geophys. Res. Lett., 34, L13801, 10.1029/2007GL029979, 2007.
Zhang, Q., Jimenez, J. L., Canagaratna, M. R., Ulbrich, I. M., Ng, N. L., Worsnop, D. R., and Sun, Y.: Understanding atmospheric organic aerosols via factor analysis of aerosol mass spectrometry: A review, Anal. Bioanal. Chem., 401, 3045-3067, 2011.

Ziemann, P. J. and Atkinson, R.: Kinetics, products, and mechanisms of secondary organic aerosol formation, Chem. Soc. Rev., 41, 6582-6605, doi:10.1039/c2cs35122f, 2012. 